\title{
Turbulence and hypoxia contribute to dense biological scattering layers in a Patagonian fjord system
}

\author{
Iván Pérez-Santos ${ }^{1,2}$, Leonardo Castro ${ }^{2,3,4}$, Lauren Ross ${ }^{5}$, Edwin Niklitschek ${ }^{1}$, Nicolás Mayorga ${ }^{1}$, Luis Cubillos $^{2,3}$, \\ Mariano Gutierrez ${ }^{6}$, Eduardo Escalona ${ }^{2,3}$, Manuel Castillo ${ }^{2,7}$, Nicolás Alegría ${ }^{8}$, and Giovanni Daneri ${ }^{2,9}$ \\ ${ }^{1}$ Centro i-mar, Universidad de Los Lagos, Camino a Chinquihue km 6, Puerto Montt, Chile \\ ${ }^{2}$ Centro COPAS Sur-Austral, Universidad de Concepción, Campus Concepción, Víctor Lamas 1290, \\ Casilla 160-C, código postal: 4070043, Concepción, Chile \\ ${ }^{3}$ Departamento de Oceanografía, Universidad de Concepción, Campus Concepción, Víctor Lamas 1290, \\ Casilla 160-C, código postal: 4070043, Concepción, Chile \\ ${ }^{4}$ Centro de Investigaciones de Altas Latitudes (IDEAL), Universidad Austral de Chile, Valdivia, Chile \\ ${ }^{5}$ Department of Civil and Environmental Engineering, University of Maine, 5711 Boardman Hall, Orono, \\ ME 04469-5711, USA \\ ${ }^{6}$ Universidad Nacional Federico Villareal, Facultad de Oceanografía, Pesquerías y Ciencias Alimentarias, \\ Calle Francia 726, Miraflores, Lima, Peru \\ ${ }^{7}$ Centro de Observación Marino para Estudios de Riesgo en Ambientes Costeros, Facultad de Ciencias del Mar \\ y de Recursos Naturales, Universidad de Valparaíso, Valparaiso, Chile \\ ${ }^{8}$ Instituto de Investigaciones Pesqueras, Talcahuano, Chile \\ ${ }^{9}$ Centro de Investigaciones en Ecosistemas de la Patagonia (CIEP), Coyhaique, Chile
}

Correspondence: Iván Pérez-Santos (ivan.perez@ulagos.cl)

Received: 22 October 2017 - Discussion started: 24 October 2017

Revised: 14 September 2018 - Accepted: 19 September 2018 - Published: 9 October 2018

\begin{abstract}
The aggregation of plankton species along fjords can be linked to physical properties and processes such as stratification, turbulence and oxygen concentration. The goal of this study is to determine how water column properties and turbulent mixing affect the horizontal and vertical distributions of macrozooplankton along the only northern Patagonian fjord known to date, where hypoxic conditions occur in the water column. Acoustic Doppler current profiler moorings, scientific echo-sounder transects and in situ plankton abundance measurements were used to study macrozooplankton assemblages and migration patterns along Puyuhuapi Fjord and Jacaf Channel in Chilean Patagonia. The dissipation of turbulent kinetic energy was quantified through vertical microstructure profiles collected throughout time in areas with high macrozooplankton concentrations. The acoustic records and in situ macrozooplankton data revealed diel vertical migrations (DVM) of siphonophores, chaetognaths and euphausiids. In particular, a dense biological backscattering layer was observed along Puyuhuapi Fjord
\end{abstract}

between the surface and the top of the hypoxic boundary layer $(\sim 100 \mathrm{~m})$, which limited the vertical distribution of most macrozooplankton and their DVM, generating a significant reduction of habitat. Aggregations of macrozooplankton and fishes were most abundant around a submarine sill in Jacaf Channel. In this location macrozooplankton were distributed throughout the water column $(0$ to $\sim 200 \mathrm{~m})$, with no evidence of a hypoxic boundary due to the intense mixing near the sill. In particular, turbulence measurements taken near the sill indicated high dissipation rates of turbulent kinetic energy $\left(\varepsilon \sim 10^{-5} \mathrm{~W} \mathrm{~kg}^{-1}\right)$ and vertical diapycnal eddy diffusivity $\left(K_{\rho} \sim 10^{-3} \mathrm{~m}^{2} \mathrm{~s}^{-1}\right)$. The elevated vertical mixing ensures that the water column is well oxygenated (3$6 \mathrm{~mL} \mathrm{~L}^{-1}, 60 \%-80 \%$ saturation), creating a suitable environment for macrozooplankton and fish aggregations. Turbulence induced by tidal flow over the sill apparently enhances the interchange of nutrients and oxygen concentrations with the surface layer, creating a productive environment for many 
marine species, where the prey-predator relationship might be favored.

\section{Introduction}

Spatial and temporal variability in plankton assemblages have been linked to oceanographic features and processes such as water column stratification, tidal mixing and turbulence, frontal structures, advection, and secondary circulation in estuaries and fjords (Govoni et al., 1989; Rodriquez et al., 1999; Lee et al., 2005; Lough and Manning, 2001; Munk et al., 2002; Meerhoff et al., 2013, 2015). In fjords, residual flows resemble typical estuarine gravitational circulation with landward flow at depth and seaward flow at the surface. It has been found that residual flows in fjords can retain planktonic larvae inside the system (Dyer, 1997; North and Houde, 2001, 2004; Meerhoff et al., 2015). Another recent study has shown that advection can influence the import and export of zooplankton in a fjord depending on the depth at which the zooplankton are located, which can potentially affect the community composition, biomass, productivity and distribution of zooplankton in the fjord (Basedow et al., 2004). Moreover, horizontal mixing of along-channel density gradients has been shown to induce lateral circulation (Farmer and Feeland, 1983), which in turn affects larval distributions in fjord systems (Meerhoff et al., 2015).

Other recent studies have investigated how tidal asymmetries in mixing, and thus tidal variations in stratification, affect ichthyoplankton and zooplankton assemblages (Oviatt, 1981; Lee et al., 2005). Lee et al. (2005) found that variations in stratification throughout a tidal cycle affected both overall abundance and species composition of zooplankton in the Irish Sea. However, they did not have the tools to relate the hydrodynamic and hydrographic variability in this region to vertical and horizontal distributions of fish larvae and zooplankton. Another study by Oviatt (1981) found that zooplankton concentrations were lower in laboratory tanks than in nature (Narragansett Bay, USA). Since this was not due to the physical action of mixing (induced by paddles in the tank), they hypothesized that tank confinement and turbulence had broken down vertical segregation between adults and juveniles, resulting in increased cannibalism. While vertical segregation of zooplankton groups, probably related to different trophic guilds, has been confirmed by several studies (e.g., Haury et al., 1990), this segregation can be reduced by turbulent processes enhancing contact between prey and predators (Visser and Stips, 2002; Visser et al., 2009). For instance, available theoretical models predict optimal prey consumption at dissipation rates of turbulent kinetic energy $(\varepsilon)$ between $10^{-6}$ and $10^{-4} \mathrm{~W} \mathrm{~kg}^{-1}$ (Lewis and Pedley, 2001). In fjords, topographic conditions are extremely irregular (Inall and Gillibrand, 2010), inducing high turbulence and enhanced vertical mixing, particularly at sills (Klymak and Gregg, 2004; Whitney et al., 2014). However, enhanced pro-

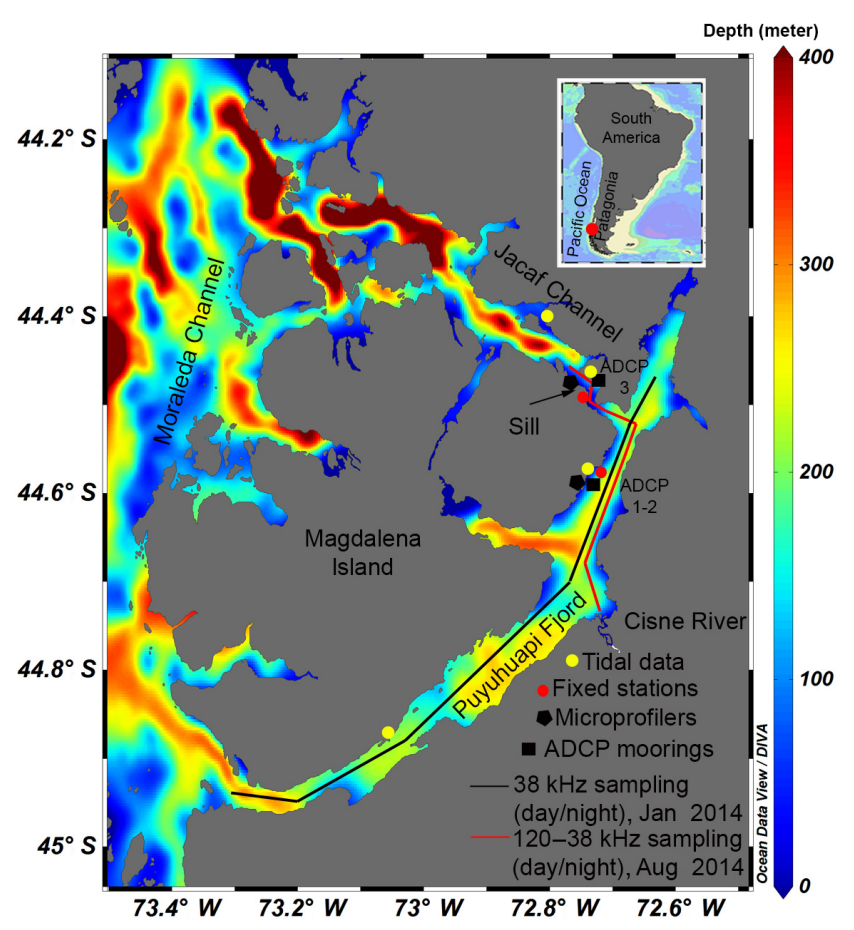

Figure 1. Study area in relation to South America and the Pacific Ocean shown in the inset. The main figure enlarges the study area (Puyuhuapi Fjord and Jacaf Channel) and indicates the instruments used for data collection, fixed point station positions and the sill location near the head of Jacaf Channel. The contours indicate the depth of the fjords.

ductivity, oxygenation and/or local retention may occur at these same highly turbulent areas. For example, turbulence is known to mix freshwater inflow with deep, dense ocean water, allowing for oxygenation of the deeper layers (MacCready et al., 2002; Peters and Bokhorst, 2001) and these turbulent eddies can impact phytoplankton bloom growth (Cloern, 1991; Koseff et al., 1993). Therefore, additional field studies are needed to confirm the relationship between mixing-induced physical forcing, such as wind or advection, and vertical abundance patterns and species composition in fjords and other estuarine systems. One of the principal questions that will be addressed in this study is what is the contribution of turbulence to the mixing of fjord water column properties (e.g., temperature, salinity and dissolved oxygen) and to the aggregation of macrozooplankton at certain depths (scattering layers) along north Patagonian fjords and channels, emphasizing the role of sills in some locations (e.g., Jacaf Channel, Fig. 1)?

Dissolved oxygen (DO) is the most important dissolved gas in the ocean as it sustains marine life and ensures ecosystems health. Most of the world's oceans are oxygenated; however, there are some regions of low DO, referred to as hypoxic zones, and if their DO concentrations are equal to or close to $0 \mathrm{~mL} \mathrm{~L}^{-1}$, they are known as "Dead Zones" (Díaz et 
al., 2001; Ekau et al., 2010; Hauss et al., 2016). Throughout the world's oceans there exist areas where hypoxic conditions are permanent and where the DO is significantly lower than well-oxygenated areas (e.g., $<20 \mu \mathrm{M}$ or $0.31 \mathrm{mLL}^{-1}$ ). These areas are known as oxygen minimum zones (OMZs) and due to the upwelling associated with them, they experience elevated primary production at the surface (Mass et al., 2014; Hauss et al., 2016; Seibel et al., 2016). The major ocean OMZs are located in the eastern South Pacific and North Pacific, the Arabian Sea, the Bay of Bengal (Indian Ocean), west Bering Sea, the Gulf of Alaska, and the eastern North Atlantic, covering around $8 \%$ of the total ocean $(\sim$ 30 million $\mathrm{km}^{2}$; Paulmier and Ruiz-Pino, 2009; Fuenzalida et al., 2009; Hauss et al., 2016). The eastern South Pacific OMZ (ESP-OMZ), present along the Chilean coast, represents an area of 9.8 million $\mathrm{km}^{2}$ ( $2.6 \%$ of the total ocean; Fuenzalida et al., 2009). Even the ESP-OMZ decreased and disappeared south of $\sim 37^{\circ} \mathrm{S}$; however, water with low DO (2$3 \mathrm{~mL} \mathrm{~L}^{-1}$ ), associated with the Equatorial Subsurface Water (ESSW), is still present up to $44^{\circ} \mathrm{S}$ (Silva et al., 2009). The ESSW infiltrates Patagonian fjords and channels and moves northward and southward $\left(41.5-44^{\circ} \mathrm{S}\right)$ depending on the marine topography (Sievers and Silva, 2008).

Hypoxic conditions $\left(<2 \mathrm{~mL} \mathrm{~L}^{-1}\right)$ have been detected in four regions of Patagonia (Puyuhuapi Fjord, Jacaf Channel, Aysén Fjord and the Almirante Montt Gulf), and in each region the oxygen depleted zones are mainly located at the fjord heads and down to $100 \mathrm{~m}$ of depth (Silva and Vargas, 2014; Schneider et al., 2014). Some of the main contributors to hypoxia in Patagonian fjords and channels have been found to be (1) water column stratification causing separation between poorly oxygenated bottom water and oxygenated surface waters, (2) DO consumption by degradation of organic matter (autochthonous and allochthonous), (3) low ventilation due to the presence of deep bathymetric microbasins, (4) advection of the ESSW and (5) anthropogenic activities such as industrial and sewage discharge, riverine inputs of nutrients, agriculture activities, aquaculture, etc. (Sievers and Silva, 2008; Silva and Vargas, 2014; Schneider et al., 2014).

Hypoxia is known to have a significant impact on plankton distribution and development, hence on the health of the ecosystem as a whole (Ekau et al., 2010; Mass et al., 2014; Hauss et al., 2016; Seibel et al., 2016). Some species can tolerate hypoxic water, e.g., smaller species, euphausiids and jellyfish can live in under $30 \%$ oxygen saturation and dissolved oxygen concentrations of $1.6 \mathrm{~mL} \mathrm{~L}^{-1}$. Other taxa, such as some copepods and fishes, may be more sensitive to hypoxia and have preference for oxygen saturations of $50 \%-100 \%$ and DO concentrations of $2.6-5.2 \mathrm{~mL} \mathrm{~L}^{-1}$ (Ekau et al., 2010; Mass et al., 2014; Hauss et al., 2016; Seibel et al., 2016). The sensitivity of species to tolerate different oxygen concentrations, however, may vary among organisms from different environments, e.g., coastal upwelling zone, fjords systems and OMZs. Although hypoxic condi- tions have been detected in four regions of Patagonia (Silva and Vargas, 2014; Schneider et al., 2014), no relationship has been determined with the zooplankton species that inhabit this ecosystem. Therefore, the second question that motivates this study is how do hypoxic conditions affect the distribution and aggregation of macrozooplankton species? This question will be addressed by investigating Puyuhuapi Fjord and Jacaf Channel, two of the four hypoxic ecosystems in Patagonia.

In Patagonian fjords, a comprehensive description of zooplankton distribution patterns has been provided by Palma (2008), considering a total of 220 in situ plankton samples from a number of depth strata between the surface and $\sim 200 \mathrm{~m}$. Main zooplankton groups included siphonophores, chaetognaths, cladocerans, copepods and euphausiids. Although a positive north-to-south gradient in the abundance of major zooplankton species was found, potential relationships between the vertical distributions and environmental variables were not deeply assessed. A later study by Landaeta et al. (2013) investigated the vertical distribution of microzooplankton and fish larvae in Steffen Fjord $\left(47.4^{\circ} \mathrm{S}\right)$ at four depth strata $(0-10,10-25,25-50$ and 50 $100 \mathrm{~m}$ ) during November 2008. Copepod nauplii and copepodites of Acartia tonsa together with Maurolicus parvipinnis fish larvae were observed around the pycnocline region, suggesting that the vertical structure of the water column might play a role in larval fish distribution. More recently, studies on zoo- and ichthyoplankton vertical distributions in the Reloncaví Fjord revealed that DVM timing might be modified by the tidal regime that is particularly strong in this area (Castro et al., 2014). However, none of these studies provided explicit assessments of the relationships between the vertical distribution of zooplankton and turbulent mixing or water column properties.

Most studies carried out in Chilean coastal waters, including those mentioned above, have relied on plankton nets and other collecting devices (pumps) deployed in single locations (fixed stations). An alternate approach is to use acoustic techniques, which can provide high-resolution data on zooplankton DVM patterns (Valle-Levinson et al., 2014; DíazAstudillo et al., 2017) and segregation patterns throughout the water column (Sato, 2013; Sato et al., 2016). For instance, DVM patterns of dense krill aggregations have been detected using acoustic Doppler current profilers (ADCP) moored around the Antarctic Peninsula, the Kattegat Channel and off Funka Bay, Japan (Buchholz et al., 1995; Lee et al., 2004; Zhou and Dorland, 2004; Brierley et al., 2006). In Chilean fjords, ADCPs have been used to identify changes in vertical distribution and DVM patterns of zooplankton (e.g., from normal diel to twilight vertical migrations) over several months in the Reloncaví Fjord (Valle-Levinson et al., 2014). These studies, although novel at describing temporal variations in zooplankton patterns, focused mainly on the behavior of a particular species, but again did not consider how the vertical distribution of zooplankton is modified by 
water column conditions (e.g., temperature, salinity, oxygen and turbulence).

Compared to ADCPs, scientific echo sounders are characterized by narrower beam angles, lower frequencies and longer ranges. They have also been used to provide valuable qualitative and quantitative information on various aquatic species and communities, from zooplankton to large predators (Ballón et al., 2011). Overall, macrozooplankton can be acoustically identified and virtually separated from other organisms, such as fish, by considering their acoustic properties (Logerwell and Wilson, 2004; Mosteiro et al., 2004; Simmonds and MacLennan, 2005). Although the use of several frequencies does not necessarily increase precision (Horne and Jech, 1999), the use of at least two frequencies (38 and $120 \mathrm{kHz}$ ) is currently a standard practice in zooplankton studies as identification methods developed by Ballón et al. (2011) and others can be utilized.

The present study aims to evaluate the effects of water column properties, such as dissolved oxygen and turbulent mixing, on the vertical distribution of dominant macrozooplankton groups along a Patagonian fjord system. To achieve this goal, ADCP and scientific echo-sounder data were combined with biological observations from in situ stratified zooplankton samples and water column measurements from microstructure profilers and conductivity-temperature-depthoxygen (CTDO) profilers. According to the information presented in this section, the principal hypotheses of this manuscript are (1) the pervasive hypoxic layer existing in the Puyuhuapi Fjord limits DVM and the overall distribution of macrozooplankton to the first $100 \mathrm{~m}$ depth of the water column, reducing the habitat of these species and (2) the higher turbulence originated by the tidal regime around sills favors the mixing of the water column, deepens the hypoxic layer, injects nutrients and, thus, increases primary production. Therefore, macrozooplankton exhibit higher densities and extend deeper in the water column around submarine sills.

\section{Study area}

Patagonian fjords extend from $41^{\circ}$ to $56^{\circ} \mathrm{S}$, and are typically deep and narrow as a result of their formation during glacial progression. Their hydrography is characterized by two vertical layers, consisting of a low salinity surface layer in the first $10 \mathrm{~m}$ of the water column (resulting from rainfall and glacial melt) that overlays a subsurface salty layer originated in the Pacific Ocean (Silva and Calvete, 2002; Pérez-Santos et al., 2014). Fjord systems play an important role in primary production and carbon cycling by providing a zone where energy and particulate material are exchanged between land and marine ecosystems (Gattuso et al., 1998). The principal nutrient (nitrate) is supplied to these fjords by oceanic transport, and particularly through the intrusion of Sub-Antarctic
Water (SAAW), a water mass that may also transport some species of zooplankton (González et al., 2011, 2013).

Puyuhuapi Fjord and Jacaf Channel are representative examples of the Patagonian fjord systems. The main connection of Puyuhuapi Fjord with oceanic waters is via its southern mouth. Although a second connection to oceanic water exists via Jacaf Channel, interchange here is limited by the shallow Jacaf Channel sill, which is $50 \mathrm{~m}$ deep and $6 \mathrm{~km}$ long. Its main freshwater input (the Cisnes River) meets the fjord half way between its head and mouth (Fig. 1). Jacaf Channel is well known for its great depth $(>400 \mathrm{~m}$ ) around its connection to the Moraleda Channel, which contrasts with its very shallow sill near its connection with Puyuhuapi Fjord (Fig. 1). Seasonal hydrographic measurements along Puyuhuapi Fjord have shown a stratified water column except in late winter, when the water column became partially mixed due to a reduction in freshwater supply from rainfall and glacial melting (Schneider et al., 2014). Hypoxic conditions have been detected in Puyuhuapi Fjord below $100 \mathrm{~m}$ depth, where oxygen concentrations have been found to be as low as $1-2 \mathrm{~mL} \mathrm{~L}^{-1}$ (Schneider et al., 2014; Pérez-Santos, 2017). This observed oxygen depletion could be caused by limited ventilation due to shallow sills, or by the input of low-oxygen Equatorial Subsurface Water into the fjord (Silva and Vargas, 2014; Schneider et al., 2014). Puyuhuapi Fjord is the only northwestern Patagonian fjord known to experience such extreme hypoxic conditions. At the same time, it is an area where intense aquaculture activities have been recently developed, which reinforces the need for this study.

The study area offers an excellent opportunity for studying the impact of deep hypoxia upon macrozooplankton distribution and behavior, considering the continued increase in hypoxic regions around the world (Breitburg et al., 2018). Moreover, the presence of a sill in Jacaf Channel, in the vicinity of its connection to the Puyuhuapi Fjord, opens the possibility to investigate the influence of vertical mixing (Farmer and Freeland, 1983; Inall and Gillibrand, 2010) upon water quality, especially upon dissolved oxygen concentration, injection of nutrients from subsurface oxygen rich layers, enhancement of primary production and, finally, upon the density of different zooplankton species (Pantoja et al., 2011). Furthermore, the location of an oceanographic buoy in the northern part of Puyuhuapi Fjord (Schneider et al., 2014) is a useful platform to carry out in situ experiments combined with oceanographic moorings.

\section{Data collection and methodology}

\subsection{Water column properties}

Hydrographic surveys were conducted during May and November 2013 and January and August 2014 in Puyuhuapi Fjord and Jacaf Channel (Fig. 2, Table 1). These profiles were obtained with a SeaBird $25 \mathrm{CTDO}$, sampling at $8 \mathrm{~Hz}$ with a 

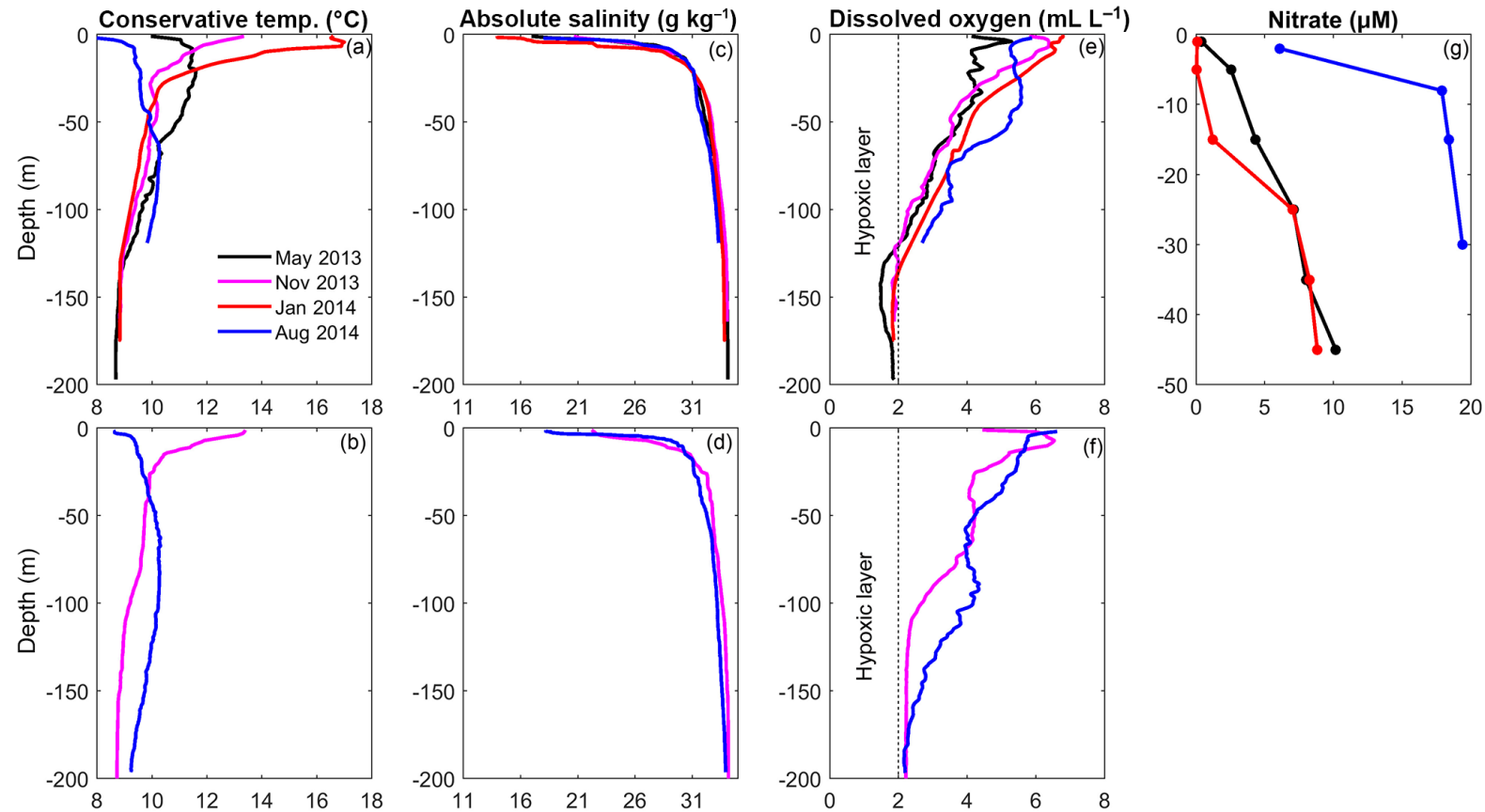

Figure 2. (a, c, e ,g) Profiles of temperature (a, b), salinity (c, d), dissolved oxygen (e, f) and nitrate (g) collected during different oceanographic campaigns in the northern central part of Puyuhuapi Fjord and $(\mathbf{b}, \mathbf{d}, \mathbf{f})$ in the eastern region of the Jacaf Channel.

descent rate of $\sim 1 \mathrm{~m} \mathrm{~s}^{-1}$. The data collected, whose nominal vertical resolution was $\sim 12 \mathrm{~cm}$, were averaged into $1 \mathrm{~m}$ bins, following SeaBird recommendations. The conservative temperature $\left({ }^{\circ} \mathrm{C}\right)$ and absolute salinity $\left(\mathrm{g} \mathrm{kg}^{-1}\right)$ were calculated according to the Thermodynamic Equation of Seawater 2010 (IOC et al., 2010). Additionally, nitrate samples were taken using a Niskin bottle at various depths and analyzed spectrophotometrically following the methods of Strickland and Parsons (1968). To validate CTDO measurements, in situ oxygen samples were analyzed using the Winkler method (Strickland and Parsons, 1968), carried out using a Metrohm burette (Dosimat plus 865) and an automatic visual end-point detection (AULOX Measurement System).

Microstructure measurements were collected using a vertical microstructure profiler (VMP-250, Rockland Scientific, Inc.). The VMP-250 is equipped with two airfoil shear probes and two fast-response FP07 thermistors, which allowed for data recording at $512 \mathrm{~Hz}$ with a descending free fall speed of $\sim 0.7 \mathrm{~m} \mathrm{~s}^{-1}$. The micro-shear measurements permitted a direct measurement of the dissipation rate of turbulent kinetic energy $(\varepsilon)$ for isotropic turbulence, according to Lueck et al. (2002), Eq. (1),

$\varepsilon=7.5 v \overline{\left(\frac{\partial u^{\prime}}{\partial z}\right)^{2}}$

where $v$ is the kinematic viscosity, $u$ is the horizontal velocity, $z$ is the vertical coordinate axis and therefore $\overline{\left(\frac{\partial u^{\prime}}{\partial z}\right)^{2}}$ is the shear variance.
Using the values of $\varepsilon$, the diapycnal eddy diffusivity $\left(K_{\rho}\right)$ was calculated. The most used formulation was proposed by Osborn (1980),

$K_{\rho}=\Gamma \frac{\varepsilon}{N^{2}}$,

where $\Gamma$ is the mixing efficiency, generally set to 0.2 (Thorpe, 2005), and $N$ is the buoyancy frequency. Shih et al. (2005) noted that when the ratio $\varepsilon / v N^{2}$ is greater than 100 , Eq. (2) results in an overestimation. Therefore, they proposed a new parameterization for this case given by

$K_{\rho}=2 v\left(\frac{\varepsilon}{v N^{2}}\right)^{1 / 2}$.

More recently, Cuypers et al. (2012) used Eq. (2) when $\varepsilon / v N^{2}>100$, Eq. (2) when $7<\varepsilon / v N^{2}<100$, and considered null eddy diffusivity when $\varepsilon / v N^{2}<7$. This approach was followed in this study. The correlation between the dissipation rate of turbulent kinetic energy and the abundance of major zooplankton groups throughout the water column was accomplished by using a quadratic polynomial curve fit between these data sets (explained in detail in Sect. 4.6). These analyses were only applied to measurements collected at the fixed station in Puyuhuapi Fjord, because the VMP250 was not available during the measurement campaign in Jacaf Channel. 
Table 1. Data set collected during oceanographic campaigns in Puyuhuapi Fjord and Jacaf Channel.

\begin{tabular}{|c|c|c|c|c|}
\hline Location & Date & Season & Data measured & Instruments \\
\hline \multirow[t]{7}{*}{$\begin{array}{l}\text { Puyuhuapi } \\
\text { Fjord }\end{array}$} & 8-27 May 2013 & Fall & $\begin{array}{l}\text { - Acoustic data } \\
307.7 \mathrm{kHz} \\
\text { - Zooplankton } \\
\text { - Hydrography } \\
\text { - Nitrate }\end{array}$ & $\begin{array}{l}\text { - ADCP-1 RDI } \\
\text { - WP2 net } \\
\text { - CTD SBE-25 } \\
\text { Spectrophotometry }\end{array}$ \\
\hline & 22 November 2013 & Spring & $\begin{array}{l}\text { - Turbulence } \\
\text { - Hydrography }\end{array}$ & $\begin{array}{l}\text { - VMP-250 } \\
\text { - CTD SBE-25 }\end{array}$ \\
\hline & 22-25 January 2014 & Summer & $\begin{array}{l}\text { - Acoustic data } \\
307.7 \mathrm{kHz} \\
\text { - Acoustic data } \\
38 \mathrm{kHz} \\
\text { - Zooplankton } \\
\text { - Turbulence } \\
\text { - Hydrography } \\
\text { - Nitrate }\end{array}$ & $\begin{array}{l}\text { - ADCP-2 RDI } \\
\text { - SIMRAD EK60 } \\
\text { - Tucker Trawl net } \\
\text { - VMP-250 } \\
\text { - YSI } 6600 \\
\text { Spectrophotometry }\end{array}$ \\
\hline & 17-19 August 2014 & Winter & $\begin{array}{l}\text { - Acoustic data } \\
38 \text { and } 120 \mathrm{kHz} \\
\text { - Zooplankton } \\
\text { - Hydrography } \\
\text { - Nitrate }\end{array}$ & $\begin{array}{l}\text { - SIMRAD EK60 } \\
\text { - Tucker Trawl net } \\
\text { - CTD SBE-25 } \\
\text { Spectrophotometry }\end{array}$ \\
\hline & February-June 2016 & $\begin{array}{l}\text { Summer- } \\
\text { Fall }\end{array}$ & $\begin{array}{l}\text { - Tidal data } \\
\text { (south) }\end{array}$ & - HOBO U20 \\
\hline & February-November 2016 & $\begin{array}{l}\text { Summer- } \\
\text { Spring }\end{array}$ & $\begin{array}{l}\text { - Tidal data } \\
\text { (north) }\end{array}$ & - HOBO U20 \\
\hline & 16 June 2016 & Fall & - Hydrography & - CTD SBE-25 \\
\hline \multirow[t]{4}{*}{ Jacaf Channel } & April-November 2012 & $\begin{array}{l}\text { Fall- } \\
\text { Spring }\end{array}$ & - Tidal data & - HOBO U20 \\
\hline & 21 November 2013 & Spring & $\begin{array}{l}\text { - Turbulence } \\
\text { - Hydrography }\end{array}$ & $\begin{array}{l}\text { - VMP-250 } \\
\text { - CTD SBE-25 }\end{array}$ \\
\hline & August 2014-May 2015 & $\begin{array}{l}\text { Winter- } \\
\text { Spring- } \\
\text { Summer- } \\
\text { Fall }\end{array}$ & - Tidal data & $-\mathrm{ADCP}-3$ \\
\hline & 17-19 August 2014 & Winter & $\begin{array}{l}\text { - Acoustic data } \\
38 \text { and } 120 \mathrm{kHz} \\
\text { - Zooplankton } \\
\text { - Hydrography }\end{array}$ & $\begin{array}{l}\text { - SIMRAD EK-60 } \\
\text { - Tucker Trawl net } \\
\text { - CTD SBE-25 }\end{array}$ \\
\hline
\end{tabular}

\subsection{Acoustic data}

Three types of acoustic data were collected: ADCP, single-frequency echo-sounder and dual-frequency echosounder data. ADCP measurements were obtained with two $307.7 \mathrm{kHz}$ Teledyne RDI Workhorse ADCPs, moored upwards at depths of $\sim 50 \mathrm{~m}(\mathrm{ADCP}-1)$ and $\sim 100 \mathrm{~m}$ (ADCP2 ), both moored at the same location in north-central Puyuhuapi Fjord but during different time periods (Table 1, Fig. 1). Data were collected hourly with a vertical bin size of
$1 \mathrm{~m}$, over periods of austral autumn (ADCP-1: May 2013) and spring-summer (ADCP-2: January 2014). During the final ADCP-2 mooring deployment, single-frequency data were also collected along the Puyuhuapi Fjord using a SIMRAD EK60 scientific echo sounder, running a $38 \mathrm{kHz}$ transducer (ES38B), during daytime and nighttime hours, from 22 to 25 January 2014 (black line in Fig. 1). These ADCP and single-frequency echo-sounder measurements were complemented by in situ zooplankton sampling (see Sect. 3.3 for details) carried out on 23-24 January 2014, at a fixed station 


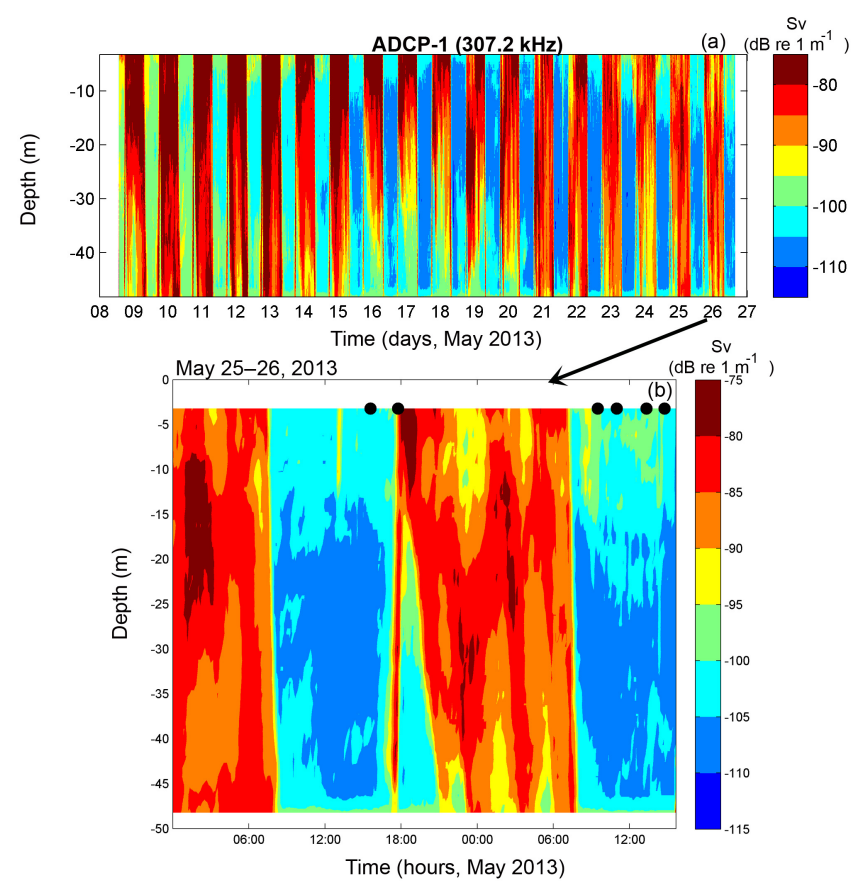

$\left(R^{2}\right)$ between acoustic data from the $38 \mathrm{kHz}$ echo sounder with hydrographic properties of the fjords (temperature, salinity and dissolved oxygen), a quadratic polynomial curve was also applied between these data sets. During this survey, two RDI Workhorse ADCP with $614.4 \mathrm{kHz}$ frequency (referenced hereafter as ADCP-3) and was moored at $\sim 30 \mathrm{~m}$ depth in the vicinity of the Jacaf sill. The near-surface placement of ADCP-3 allowed for near-surface currents to be adequately quantified.

Vessel speed during all echo-sounder surveys was maintained between 8 and 10 knots. Echo sounders were operated using a variable ping rate of $0.3-2.0$ pings per second, a pulse duration of $1.024 \mathrm{~ms}$ and output powers of 2 and $0.5 \mathrm{~kW}$ for the 38 and $120 \mathrm{kHz}$ frequencies, respectively. Calibration was made using copper spheres and standard procedures (Foote et al., 1987).

\subsubsection{Echo-sounder data analysis}

Post-processing of echo-sounder data was performed in Echoview (Myriax Inc, Tasmania, https://www.echoview. com/, last access: 2 October 2018), where noisy data considered as those collected with weak pings, in blind areas, in the near-field, with background noise or subjected to rainbow phenomenon were regarded as "bad data" and were eliminated. After this initial scrutiny and filtering step, all single-frequency echoes $(38 \mathrm{kHz}$, campaign 1$)$ of intensity $>-110 \mathrm{~dB}$ were considered and treated as a single "biological backscattering" class, which pooled all biological groups present in the study area. Dual-frequency echoes, however, were classified into three different groups following Ballón et al. (2010). These authors created an algorithm, freely distributed as an Echoview template ("FishZpkPeru38\&120.evi"), which uses both mean volume backscattering (MVBS) differences $(\triangle \mathrm{MVBS})$ and summations ( $\sum$ MVBS) between 38 and $120 \mathrm{kHz}$ to discriminate echoes into three different biological backscattering classes: fish and two macrozooplankton groups (macrozooplankton or "fluidlike" and gelatinous or "blue noise" organisms). The fluidlike group follows a sphere model (Holliday and Pieper, 1995) considered appropriate to represent cylindrical and spherical shapes, including euphausiids and large copepods, which are dominant macrozooplankton groups off Peru and Chile (Ayon et al., 2008). The algorithm is considered to be useful for 38 and $120 \mathrm{kHz}$ data from targets whose radius is $\geq 0.5 \mathrm{~mm}$ and has a dB difference of $2-19 \mathrm{~dB}$ (Ballón et al., 2010, 2011).

Given physical limitations imposed by near-field and sound-absorption effects related to the echo-sounder frequencies used (38 and $120 \mathrm{kHz}$ ), we defined and limited our analyses to an effective sampling range between 5 and $250 \mathrm{~m}$. Absorption is greater for the $120 \mathrm{kHz}$ frequency, which exhibits the shortest range, but has a greater vertical resolution than the $38 \mathrm{kHz}$ echo sounder. The $38 \mathrm{kHz}$ frequency, on the other hand, exhibits a much longer range $(>1000 \mathrm{~m})$, 

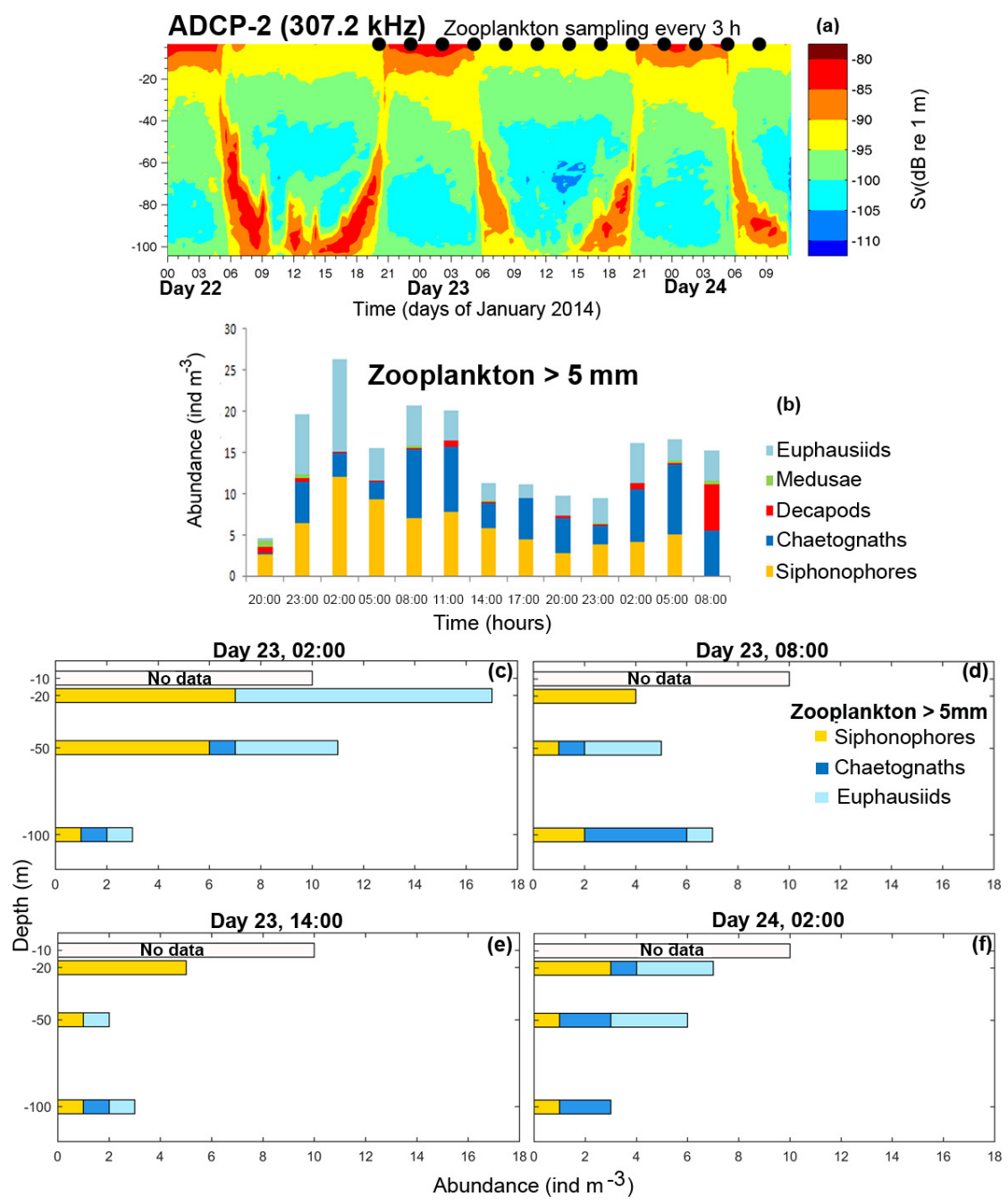

Figure 4. (a) Volume backscattering strength $\left(S_{\mathrm{V}}\right)$ calculated from the ADCP-2 backscatter signal in Puyuhuapi Fjord from 22 to 24 January 2014. The in situ zooplankton sampling (in 03:00 intervals) are represented by black dots at the surface. (b) Depth-integrated abundance of zooplankton from the surface to $100 \mathrm{~m}$ depth varying throughout time, where (b) is zooplankton $>5 \mathrm{~mm}$ in length. (c) Vertical abundance of the principal zooplankton groups on 23 January at 02:00 (nighttime) and (d, e, f) same as (c) but on 23 January at 08:00 and 14:00 (daytime) and 24 January at 02:00 (nighttime). The time reference is in local time.

but limited resolution regarding small zooplankton scatterers. It has been shown, however, to be efficient for studying macrozooplankton distributions of siphonophores, chaetognaths and euphausiids (Mair et al., 2005; Cade and BenoitBird, 2015; Ariza et al., 2016).

Volume backscattering strength $\left(S_{\mathrm{v}}, \mathrm{dB}\right.$ re $1 \mathrm{~m}^{-1}$, where re represents referenced) values from the single-frequency and from each of the three dual-frequency virtual echograms were integrated and rescaled into the customary index "nautical area scattering coefficient" (NASC, in units of $\mathrm{m}^{2} \mathrm{n} \mathrm{mi}^{2}$, where $n m i^{2}$ represents square nautical miles), using a grid of $20 \mathrm{~m}$ (depth) by $50 \mathrm{~m}$ (distance). Since NASC lies on the linear domain, it can be considered proportional to and suitable for indexing targets abundance (Ballón et al., 2011).
Quadratic polynomial models were fit to assess the statistical relationship $\left(R^{2}\right)$ between biological scattering (singlefrequency integrated data) and the hydrographic variables measured in each fjord (temperature, salinity and DO).

\subsubsection{Acoustic data analysis from ADCPs}

ADCP echo intensity was converted to mean volume backscattering strength $\left(S_{\mathrm{v}}, \mathrm{dB}\right.$ re $\left.1 \mathrm{~m}^{-1}\right)$, as done for scientific echo-sounder data, following the conversion formula:

$$
\begin{aligned}
S_{\mathrm{V}} & =C+10 \log \left[\left(T_{x}+273.16\right) R^{2}\right]-L_{\mathrm{DBW}}-P_{\mathrm{DBW}} \\
& +2 \alpha R+K_{c}\left(E-E_{\mathrm{r}}\right),
\end{aligned}
$$



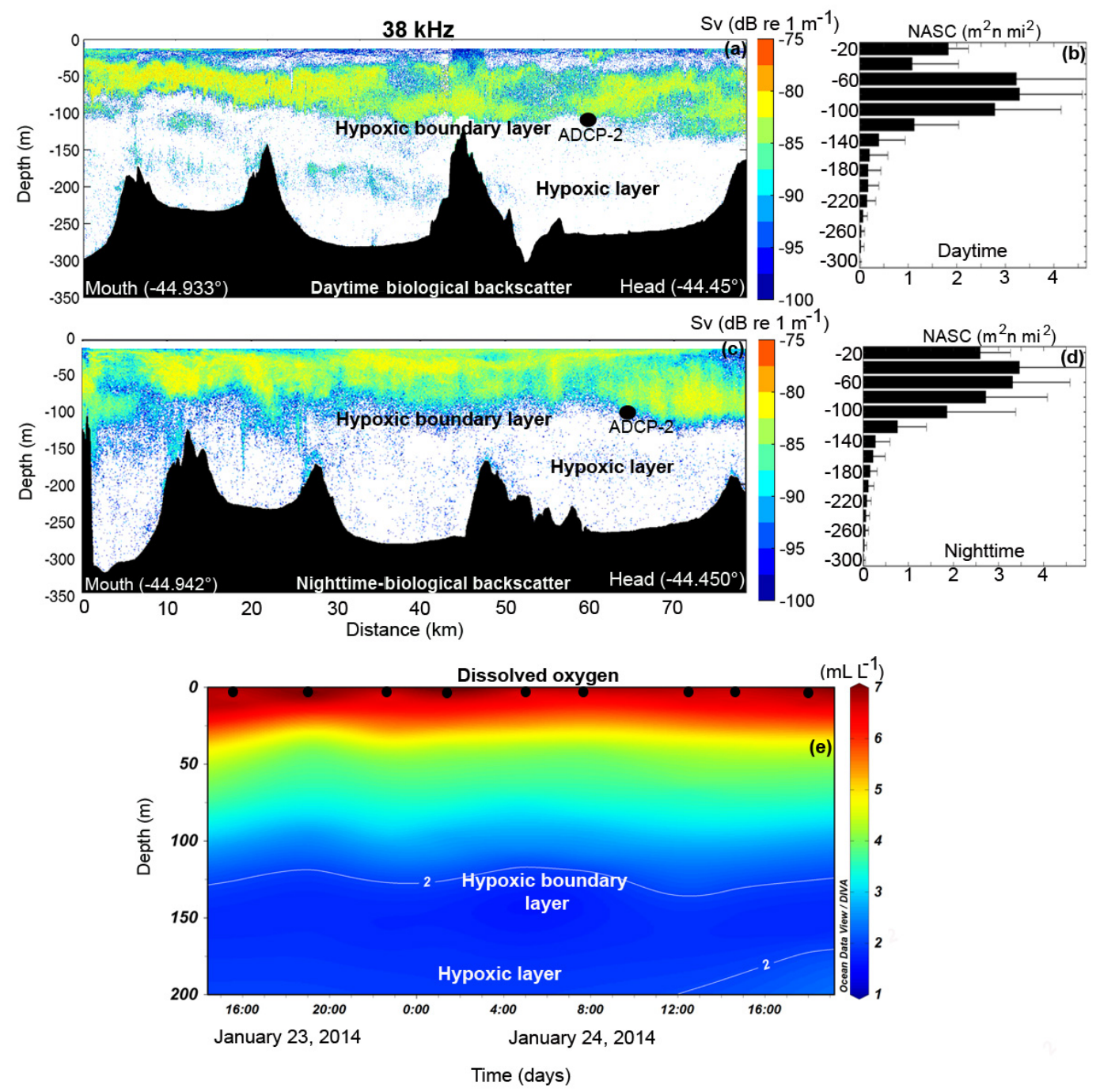

Figure 5. Single-frequency ( $38 \mathrm{kHz})$ scientific echo-sounder transect conducted along the Puyuhuapi Fjord during the summertime field campaign (January 2014). Distribution indicated by colors representing $S_{\mathrm{V}}$. (a) Daytime transect of echo-sounder measurements $\left(S_{\mathrm{V}}\right)$ throughout depth ( $y$ axis) from the mouth $(0 \mathrm{~km})$ to the head $(80 \mathrm{~km})$ of Puyuhuapi Fjord on 22 January 2014. (b) Average profiles derived from the nautical area scattering coefficient (NASC) from the daytime transect with standard deviation bars. (c) Same as (a), but for the nighttime starting at 21:57 (local time) 24 January through early in the morning of 25 January 2014. (d) Same as (b) but for the nighttime. The ADCP-2 mooring location is marked with a black dot in (a) and (c). (e) Dissolved oxygen profiles (black dots) obtained approximately every $3 \mathrm{~h}$ (close to the position of ADCP-2 mooring) from 23 to 24 January 2014. The location of the hypoxic boundary layer is depicted by the white contour line of $2 \mathrm{mLL}^{-1}$.

where $C$ is a sonar-configuration scaling factor $(-148.2 \mathrm{~dB}$ for the Workhorse Sentinel), $T_{x}$ is the temperature at the transducer $\left({ }^{\circ} \mathrm{C}\right), L_{\mathrm{DBW}}$ is $\log _{10}$ (transmit-pulse length, $L=$ $8.13 \mathrm{~m}$ ), $P_{\mathrm{DBW}}$ is $\log _{10}$ (output power, $15.5 \mathrm{~W}$ ), $\alpha$ is the absorption coefficient $\left(\mathrm{dB} \mathrm{m}^{-1}\right), K_{c}$ is a beam-specific sensitivity coefficient (supplied by the manufacturer as 0.45 ), $E$ is the recorded AGC (automatic gain control), and $E_{\mathrm{r}}$ is the minimum AGC recorded (40 dB for ADCP-1 and $41 \mathrm{~dB}$ for ADCP-2). The beam-average of the AGC for the four transducers was used to obtain optimal results following the procedure in Brierley et al. (2006). Finally, $R$ is the slant range to the sample bin (m), which uses the vertical depth as a correction (Lee et al., 2004). Therefore, $R$ is expressed as,

$R=\frac{b+\frac{L+d}{2}+((n-1) d)+(d / 4)}{\cos \zeta} \frac{\bar{c}}{c_{I}}$,

where $b$ is the blanking distance $(3.23 \mathrm{~m}), L$ is the transmit pulse length $(8.13 \mathrm{~m}), d$ is the length of the depth cell ( $1 \mathrm{~m}), n$ is the depth cell number of the particular scattering layer being measured, $\zeta$ is the beam angle $\left(20^{\circ}\right), \bar{c}$ is the average sound speed from the transducer to the depth cell 

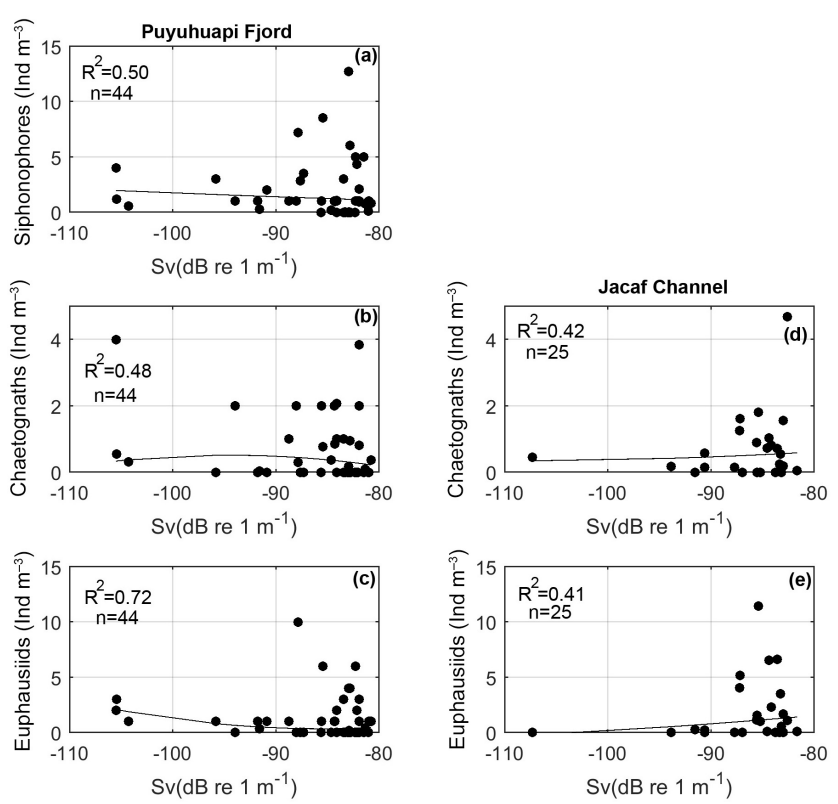

Figure 6. Scatter plot of volume backscattering strength $\left(S_{\mathrm{V}}\right)$ from $38 \mathrm{kHz}$ frequency and the most abundant macrozooplankton species obtained in the in situ fixed stations carried out in Puyuhuapi Fjord (a, b, c) during 22-24 January 2014 and in Jacaf Channel (d, e) during 18-19 August 2014.

$\left(1453 \mathrm{~m} \mathrm{~s}^{-1}\right)$ and $c_{\mathrm{I}}$ is the nominal sound speed used by the instrument $\left(1454 \mathrm{~m} \mathrm{~s}^{-1}\right)$.

\subsection{In situ zooplankton sampling}

In situ mesozooplankton samples were collected with a WP2 net $(60 \mathrm{~cm}$ diameter mouth opening, $300 \mu \mathrm{m}$ mesh, flowmeter mounted in the net frame) towed vertically from $50 \mathrm{~m}$ to the surface in May 2013, and with a Tucker Trawl $\left(1 \mathrm{~m}^{2}\right.$ mouth opening, $300 \mu \mathrm{m}$ mesh with flowmeter) used to obtain stratified oblique tows in January and August 2014 (Table 1). All samples were preserved in a $5 \%$ formaldehyde solution. Zooplankton abundances were standardized to individuals per $\mathrm{m}^{3}$ of filtered seawater. WP2 vertical tows consisted of five depth intervals from surface to $50 \mathrm{~m}$, every $10 \mathrm{~m}$ (0-10, 10-20, 20-30, 30-40, 40-50 m).

Stratified Tucker tows considered four depth strata: 0 $10,10-20,20-50$ and $50-100 \mathrm{~m}$ in the Puyuhuapi Fjord. In Jacaf Channel, the stratified sampling included five depth strata: $0-10,10-20,20-50,50-100$ and $100-150 \mathrm{~m}$. The hauling speed for both nets was between $2-3$ knots. Sampling occurred during a $36 \mathrm{~h}$ period every $3 \mathrm{~h}$ from 22 to 24 January 2014 (Puyuhuapi Fjord) and every 5-6h from 18 to 19 August 2016 (Jacaf Channel) (Fig. 1, red dots). At all sites and dates, zooplankton species were identified, sorted into functional groups, measured (length) and classified into size classes using a $5 \mathrm{~mm}$ length threshold. To determine the correlation $\left(R^{2}\right)$ between the $S_{\mathrm{v}}$ records from the

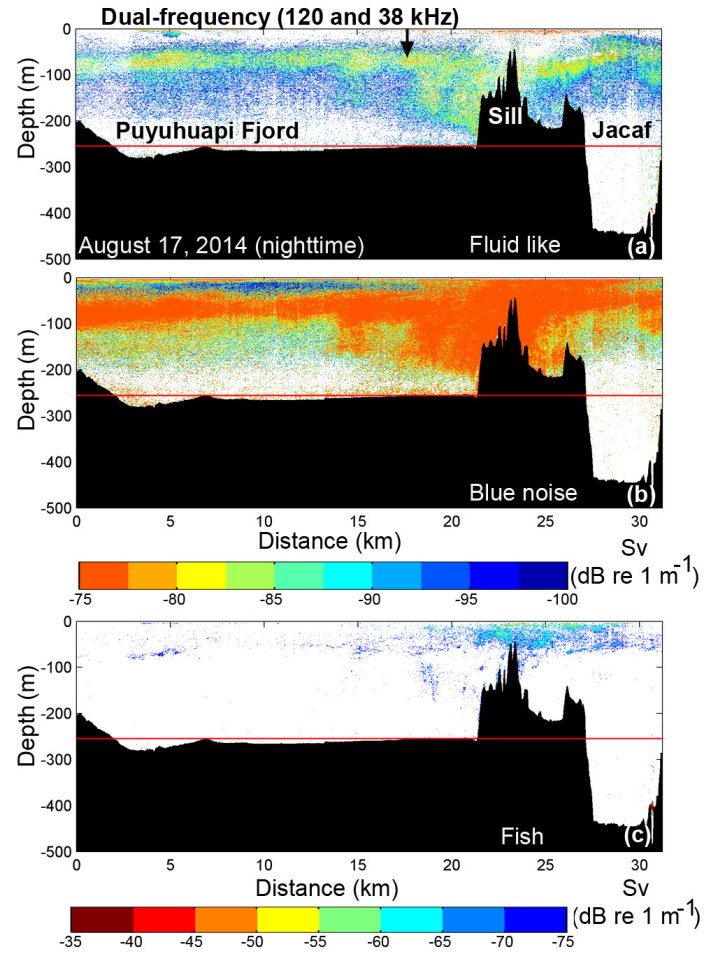

Figure 7. Dual-frequency (38 and $120 \mathrm{kHz}$ ) scientific echo-sounder transects along Puyuhuapi Fjord (0-18 km) and Jacaf Channel (18$35 \mathrm{~km}$ ) during nighttime on 17 August 2014. (a) Fluid-like and (b) blue noise echograms for zooplankton and (c) the fish echogram. Distribution indicated by colors representing $S_{\mathrm{V}}$ values. The black arrow in (a) represents the entrance to Jacaf Channel. Horizontal red lines in (a, b, c) denote lower limits of usable acoustic data $(250 \mathrm{~m})$.

$38 \mathrm{kHz}$ transducer and the major macrozooplankton groups (Siphonophores, Chaetognaths and Euphausiids), a quadratic polynomial curve was also applied between these data sets (further details in Sect. 4.3).

\subsection{Tidal harmonic analysis}

The tidal constituents were computed using HOBO U20 water level loggers and the pressure sensor from ADCP-3 (Tables 1-2, Fig. 1). A tidal harmonic analysis was applied to the sea level time series according to Pawlowicz et al. (2002), which considers the algorithms of Godin (1972) and Foreman $(1977,1978)$. We classified tides by the dominant period of the observed tide based on the form factor $(F)$, defined by the ratio between the sum of the amplitudes of the two main diurnal constituents (principal lunar declinational, $O_{1}$ and luni-solar declinational, $K_{1}$ ) and the sum of the amplitudes of the two main semidiurnal constituents (principal lunar, $M_{2}$, and principal solar, $\left.S_{2}\right), F=\left(O_{1}+K_{1}\right) /\left(M_{2}+S_{2}\right)$ (Bearman, 1989; where $F<0.25$ semidiurnal, $0.25<F<1.5$ mixed semidiurnal and $F>3.0$ diurnal). 
Table 2. Harmonic analysis implemented to water level time series in Puyuhuapi Fjord and Jacaf Channel.

\begin{tabular}{|c|c|c|c|c|c|c|c|c|}
\hline \multirow[t]{2}{*}{ Sea level time series } & \multirow[t]{2}{*}{ Date } & \multirow{2}{*}{$\begin{array}{c}\text { Energy from } \\
\text { semidiurnal } \\
\text { band }\left(\mathrm{m}^{2} \mathrm{cph}^{-1}\right)\end{array}$} & \multicolumn{4}{|c|}{$\begin{array}{l}\text { Amplitude of principal } \\
\text { constituents }(\mathrm{cm})\end{array}$} & \multirow[t]{2}{*}{$\mathrm{F}$} & \multirow[t]{2}{*}{ Tidal regime } \\
\hline & & & $M_{2}$ & $S_{2}$ & $O_{1}$ & $K_{1}$ & & \\
\hline Jacaf-HOBO & April-September 2012 & 45.10 & 83.45 & 28.32 & 14.46 & 22.33 & 0.32 & Mixed semidiurnal \\
\hline Jacaf-ADCP & August 2014-May 2015 & 57.29 & 60.67 & 61.01 & 57.78 & 42.48 & 0.82 & Mixed semidiurnal \\
\hline Puyuhuapi-HOBO south & February-June 2016 & 44.45 & 81.97 & 31.51 & 13.37 & 18.36 & 0.27 & Mixed semidiurnal \\
\hline Puyuhuapi-HOBO north & February-November 2016 & 49.17 & 89.15 & 31.07 & 11.03 & 17.75 & 0.23 & Semidiurnal \\
\hline
\end{tabular}

\section{Results}

\subsection{Hydrographic features}

Temperature profiles collected in Puyuhuapi Fjord and Jacaf Channel showed a similar structure during the winter and summer campaigns (Fig. 2a, b). The largest temperature gradients were found between the surface and $\sim 70 \mathrm{~m}$ depth, ranging from 8.5 to $17^{\circ} \mathrm{C}$. A thin, fresh layer (salinity values varied from 11 to $29 \mathrm{~g} \mathrm{~kg}^{-1}$ ) was found in the first $\sim 10 \mathrm{~m}$ of the water column below which salinity varied little ( 29 to $\sim 34.2 \mathrm{~g} \mathrm{~kg}^{-1}$ ), as a result of the presence of Modified Sub-Antarctic Water (MSAAW, salinity between 31 and $33 \mathrm{~g} \mathrm{~kg}^{-1}$ ), the Sub-Antarctic Water (SAAW, salinity between 33 and $33.8 \mathrm{~g} \mathrm{~kg}^{-1}$ ) and the Equatorial Subsurface Water (ESSW, salinity $>33.8 \mathrm{~g} \mathrm{~kg}^{-1}$ ) (Fig. 2c, d). Hypoxic conditions (dissolved oxygen below $2 \mathrm{mLL}^{-1}$ and $\sim 30 \%$ saturation) were detected in Puyuhuapi Fjord below $100 \mathrm{~m}$ depth, with oxygen concentrations between 1 and $2 \mathrm{~mL} \mathrm{~L}^{-1}$ (Fig. 2e). Deep water in Jacaf Channel was more ventilated, with dissolved oxygen values above hypoxic conditions throughout the water column (Fig. 2f). The hypoxic layer was located over the depth range of the ESSW and oxygen-rich water $\left(3-6 \mathrm{~mL} \mathrm{~L}^{-1}\right)$ was observed at depths occupied by MSAAW and SAAW. Below $10 \mathrm{~m}$ depth, high nitrate concentrations were measured in Puyuhuapi Fjord, but concentrations in the winter (August, 2014) were higher than in fall (May, 2013) and summer (January, 2014) (Fig. 2g). Along with the in situ hydrographic sampling, in situ zooplankton samples were collected and will now be discussed.

\subsection{ADCP acoustic data and in situ zooplankton samples}

Volume backscatter $\left(S_{\mathrm{v}}\right)$ from ADCP-1 $(50 \mathrm{~m}$ depth, May 2013) showed large variability, ranging from high $(-90$

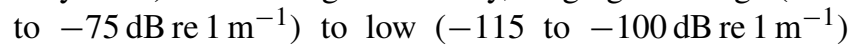
(Fig. 3a). The highest $S_{\mathrm{v}}$ values $\left(>-90 \mathrm{~dB}\right.$ re $\left.1 \mathrm{~m}^{-1}\right)$ were recorded during the night hours $(\sim 18: 00$ to $\sim$ 07:00 LT, local time; with all remaining times for in situ sampling expressed in local time), while minimum $S_{\mathrm{v}}$ values were observed in the daytime $(\sim 07: 00$ to $\sim 18: 00)$ suggesting that vertically migrating organisms from deeper waters (below ADCP-1 mooring depth of $50 \mathrm{~m}$ ) migrate upwards during nighttime
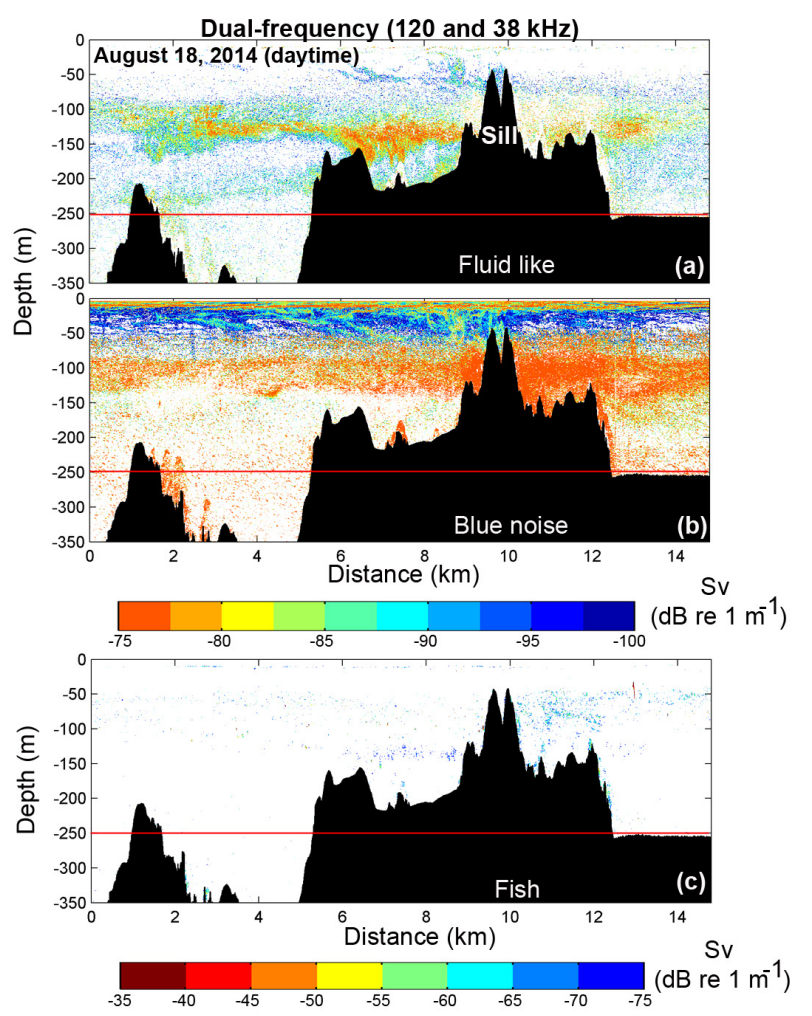

Figure 8. Dual-frequency ( 38 and $120 \mathrm{kHz}$ ) acoustic transect across Jacaf sill conducted during daytime on 18 August 2014. (a) Fluidlike echogram, (b) blue noise echogram for zooplankton and (c) the fish echogram. Distribution indicated by colors representing $S_{\mathrm{V}}$ values. Horizontal red lines in $(\mathbf{a}, \mathbf{b}, \mathbf{c})$ denote lower limits of usable acoustic data $(250 \mathrm{~m})$.

hours. From the in situ measurements of macrozooplankton collected at various depth strata in May 2013, the most abundant groups were siphonophores, chaetognaths and medusae (Fig. 3c-f). A marked change in vertical distribution and in total abundance of the macrozooplankton groups in the water column was observed from the first sampling hour (Fig. 3c) to the night sampling time $(\sim 18: 00 \mathrm{~h})$, revealing the start of the nocturnal migration to the surface (Fig. 3d) coincident with a DVM pattern as seen in the ADCP-1 backscatter data (Fig. 3a, b). 
Data from the ADCP-2 mooring (positioned deeper but at the same location as ADCP-1) from 22 to 24 January 2014 also showed a strong macrozooplankton DVM pattern, which extended down to $\sim 100 \mathrm{~m}$ depth (Fig. 4a). During daylight hours (8:00-18:00), dense aggregations were observed between 80 and $100 \mathrm{~m}$ depth, which started to ascend from 18:00 to 21:00, concentrated close to the surface at night, and began to descend at $\sim 06: 00$. In situ stratified sampling showed the most abundant macrozooplankton groups were euphausiids, siphonophores, chaetognaths, decapods and medusae (Fig. 4b-f). Euphausiids and siphonophores showed higher abundance close to a surface layer (10-20 m) during night hours (Fig. 4c, f) and at deeper layers during the daytime (Fig. 4d, e). However, euphausiids showed the clearest diel vertical migration with maximum abundance between 10 and $20 \mathrm{~m}$ layer during night hours, and at $\sim 100 \mathrm{~m}$ depth during the daytime (Fig. 4c-f). The in situ zooplankton samples were complemented by echo-sounder measurements collected along the fjord systems during the summertime and the wintertime. These measurements will now be discussed.

\subsection{Echo-sounder data}

\subsubsection{Summertime single-frequency survey}

The volume backscatter during the summer months overall showed DVM of all macrozooplankton species and a downward migration limit of $\sim 100 \mathrm{~m}$ depth due to the presence of hypoxic conditions below this depth. Summer daytime $S_{\mathrm{v}}$ values along the Puyuhuapi Fjord averaged $-89.1 \pm$ $7 \mathrm{~dB}$ re $1 \mathrm{~m}^{-1}$ and ranged between -110 and $-77.3 \mathrm{~dB}$ re $1 \mathrm{~m}^{-1}$, from the mouth to the head of the Puyuhuapi Fjord (Fig. 5a). Most biological backscatter was concentrated in the first $100 \mathrm{~m}$ of the water column, matching ADCP-2 results, which showed an increase in backscattering towards $100 \mathrm{~m}$ depth (Figs. 4a and 5a). Highest daytime NASC values were found around $80 \mathrm{~m}$ (above the hypoxic layer), reaching values of $3-3.5 \mathrm{~m}^{2} \mathrm{n} \mathrm{mi}^{2}$ (Fig. 5b). Although some backscatter occurred within the hypoxic layer (below $\sim 120 \mathrm{~m}$ depth), all dense aggregations were observed above it (Fig. 5e).

Summer nighttime biological backscattering along the Puyuhuapi Fjord (Fig. 5c) showed maximum $S_{\mathrm{v}}$ values near the surface, suggesting an ascending vertical migration of all biological backscatter. NASC profiles also showed both an increase in maximum abundances and a shift in the vertical position of the maximum values from $60-80 \mathrm{~m}$ during daytime to 40-60 m depth during nighttime (Fig. 5d). Although the water column depth extended to $\sim 300 \mathrm{~m}$, all dense backscatter aggregations were observed above $100 \mathrm{~m}$ depth during both daytime and nighttime hours (Fig. 5a, c). As DO concentrations decreased from 2 to $1 \mathrm{mLL}^{-1}$ below $100 \mathrm{~m}$ depth, biological scatterers in Puyuhuapi Fjord appeared to prefer oxygen concentrations between 3 and $7 \mathrm{mLL}^{-1}$ (Fig. 5e). The correlation between $S_{\mathrm{v}}$ values and the observed density of different zooplankton groups (in situ samples, $>5 \mathrm{~mm}$ ) was moderate. Such correlations reached values of $R^{2}=0.50$, for siphonophores (Fig. 6a), $R^{2}=0.48$ for chaetognaths (Fig. 6b) and $R^{2}=0.72$ for euphausiids (Fig. 6c). The wintertime sampling showed similar findings but was able to capture more activity in the water column due to the use of two acoustic frequencies.

\subsubsection{Wintertime dual-frequency surveys}

Wintertime dual-frequency survey data, carried out along Puyuhuapi Fjord and Jacaf Channel on 17 August $(\sim 35 \mathrm{~km}$ total transect length, Fig. 1), which allowed for the separation of total backscatter into Fish, Fluid like (FL) and Blue noise $(\mathrm{BN})$ groups (Fig. 7a, b). Total backscatter $\left(S_{\mathrm{v}}\right)$ in Puyuhuapi Fjord $(0-18 \mathrm{~km})$ showed elevated values in the first $100 \mathrm{~m}$ of the water column, but at slightly deeper depths $(50-100 \mathrm{~m})$ than in summer (Fig. 5), possibly due to bad weather conditions encountered on the sampling day. Greater intensity $\left(-80\right.$ to $-60 \mathrm{~dB}$ re $\left.1 \mathrm{~m}^{-1}\right)$ and vertical distribution range $(0-$ $220 \mathrm{~m})$ of biological backscattering values $\left(S_{\mathrm{v}}>-110 \mathrm{~dB}\right)$ were observed in Jacaf Channel, particularly around its sill (between km 18 and 32; Fig. 7). Particularly high intensities were attributed to BN and FL groups at either side of Jacaf Channel sill on both 17 and 19 August 2014 (Figs. 7 and 8). An important degree of vertical segregation between $\mathrm{BN}$ and FL groups was also observed along Jacaf Channel, with the first group concentrated between 100 and $140 \mathrm{~m}$, while the second was between 120 and $200 \mathrm{~m}$ (Figs. 7 and 8).

Continuous acoustic sampling repeated over the Jacaf Channel sill confirmed the presence of two backscattering layers: one denser layer between 100 and $150 \mathrm{~m}$ and a second less dense layer from 200 to $250 \mathrm{~m}$ (Fig. 8a, showed only the best echogram). In situ zooplankton sampling along the Jacaf Channel sill (Fig. 9f) allowed for the detection of the major macrozooplankton (e.g., chaetognaths, euphausiids and crustaceans) found during this experiment (Fig. 9ad). In general, all sampling stations were carried out during daytime, but station 4 coincided with the ascending moment of macrozooplankton, and highlighted the presence of euphausiids during this time of vertical migration (Fig. 9d). Also, station 1 showed the dominance of crustaceans in the $0-10 \mathrm{~m}$ strata. Overall the in situ zooplankton sampling and the echograms showed good agreement with the FL group (Fig. 9a-d). Furthermore, the elevated abundance of macrozooplankton groups (euphausiids and chaetognaths) found between 100-150 m depth during daytime hours (Fig. 9bf) matched well with acoustic data for the fluid-like group (Fig. 8a), but in the case of the BN group the macrozooplankton species were not clearly identified in the in situ zooplankton sampling.

A moderate correlation was found between $S_{\mathrm{v}}$ values from Jacaf Channel and zooplankton density calculated from in situ samples $\left(>5 \mathrm{~mm}\right.$ ), with $R^{2}=0.42$ for $S_{\mathrm{v}}$ vs. chaetognaths (Fig. 6d) and $R^{2}=0.41$ for $S_{\mathrm{v}}$ vs. euphausiids (Fig. 6e). Now the relationships between water column prop- 

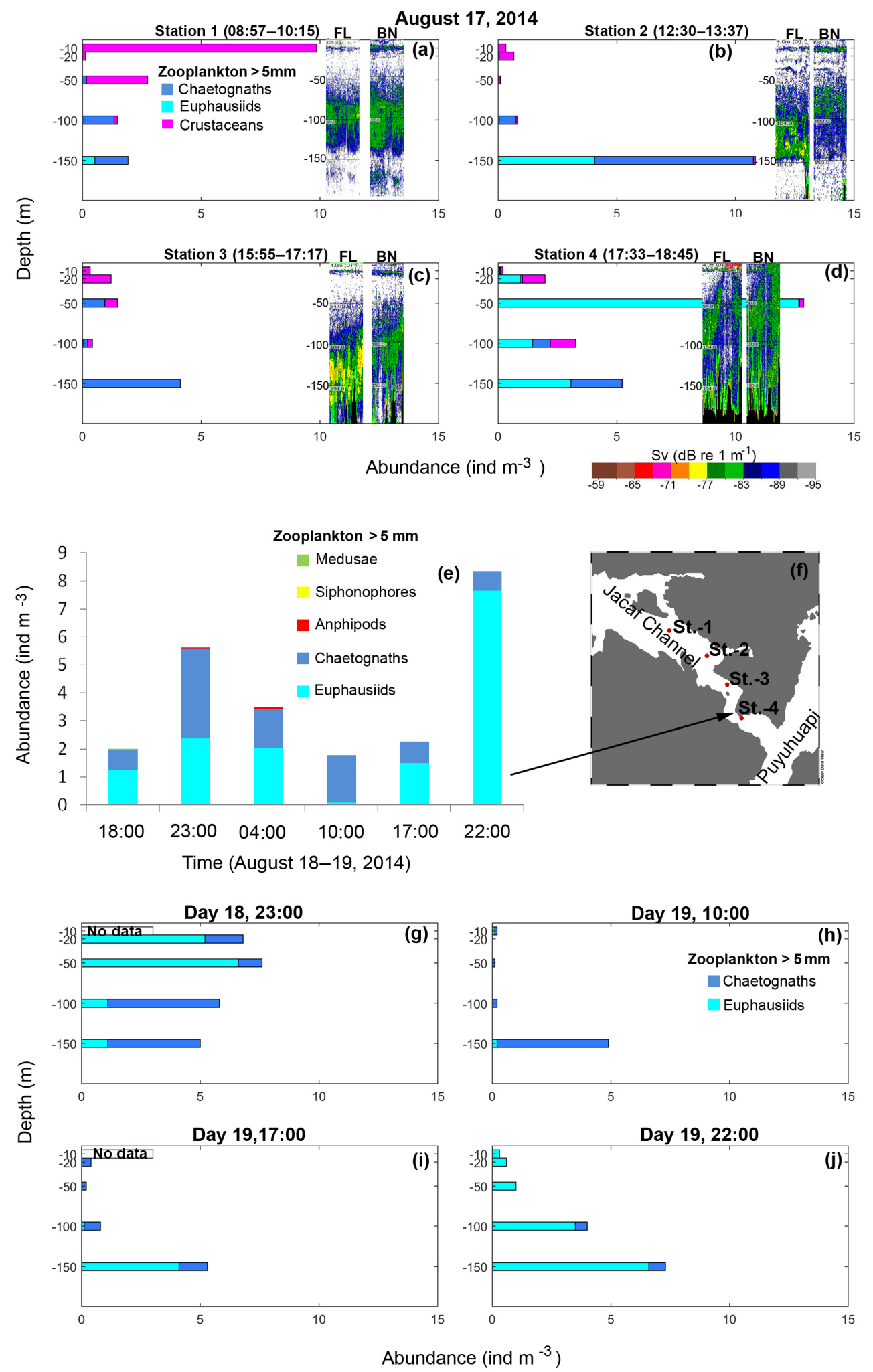

Figure 9. (a-d) In situ stratified zooplankton sampling along Jacaf Channel during 17 August 2014 and the acoustic data collected simultaneously using the dual-frequency ( 38 and $120 \mathrm{kHz}$ ) echo sounder. FL is fluid-like and BN the is blue noise group. (e) Depth-integrated abundance of macrozooplankton groups from surface to $150 \mathrm{~m}$ depth for various sampling hours. (f) Shows the station positions. (g-j) The vertical abundance of the main macrozooplankton groups found during the wintertime survey. 
erties such as temperature, salinity and DO will be compared to the acoustic and in situ macrozooplankton measurements.

\subsection{Relationships between biological scattering and water column properties}

To examine relationships between the distribution of biological scattering and water column properties, $S_{\mathrm{v}}$ values quantified from the $38 \mathrm{kHz}$ acoustic profiler were matched to the consecutive time at which CTD and DO data were captured. This was done in Puyuhuapi Channel and Jacaf Channel during the summer and winter seasons, respectively. The relationship between water temperature and $S_{\mathrm{v}}$ was weak during summer $\left(R^{2}=0.30\right)$ and winter $\left(R^{2}=0.41\right)$, with maximum $S_{\mathrm{v}}$ values occurring between 8 and $10^{\circ} \mathrm{C}$. A weak relationship was found between $S_{\mathrm{v}}$ and salinity in Puyuhuapi Fjord $\left(R^{2}=0.29\right)$ and Jacaf Channel $\left(R^{2}=0.35\right)$, with higher $S_{\mathrm{v}}$ values found in the MSAAW and SAAW water masses (salinity $>31 \mathrm{~g} \mathrm{~kg}^{-1}$ ). Both in Puyuhuapi Fjord and Jacaf Channel, $S_{\mathrm{v}}$ with DO and oxygen saturation showed the highest $R^{2}$ values $\left(R^{2} \sim 0.6\right)$. Hence, only $20.4 \%$ of total $S_{\mathrm{v}}>-$ $110 \mathrm{~dB}$ re $1 \mathrm{~m}^{-1}$ were in the hypoxic layer of Puyuhuapi Fjord, while just $1.2 \%$ were in the hypoxic layer in Jacaf Channel. Now the turbulent kinetic energy dissipation will be discussed to relate macrozooplankton assemblages to vertical mixing in the water column.

\subsection{Tidal regime}

The harmonic analysis carried out with the sea level time series obtained in Puyuhuapi Fjord and Jacaf Channel, denoted the dominance (in terms of amplitude) of the semidiurnal constituents $\left(M_{2}\right.$ and $S_{2}$; Table 2). Diurnal constituents $\left(O_{1}\right.$ and $\left.K_{1}\right)$ were also important, specifically at the Jacaf ADCP-3 station located close to the Jacaf sill region (Table 2 and Fig. 1). The contribution of diurnal constituents added the mixed character to the tidal regime in the study area. The spectral analysis implemented at all sea-level stations showed maximum energy in the semidiurnal band (Table 2), with the highest spectral energy $\left(57.29 \mathrm{~m}^{2} \mathrm{cph}^{-1}\right.$, where $\mathrm{cph}$ is cycles per hour) at Jacaf sill (Jacaf ADCP-3 station), which could be due to the extreme convergence of the channel at this location accelerating the tidal flows.

\subsection{Mixing process}

Turbulence measurements collected with the VMP-250 microstructure profiler showed high dissipation rates of turbulent kinetic energy $(\varepsilon)$ in the upper $20 \mathrm{~m}$ of the water column in Puyuhuapi Fjord and Jacaf Channel (Fig. 10). In this layer, $\varepsilon$ ranged from $10^{-7}$ to $10^{-5} \mathrm{~W} \mathrm{~kg}^{-1}$. However, below this surface layer $(<20 \mathrm{~m}$ depth $)$ the highest values were obtained around Jacaf sill $\left(\varepsilon=1.2 \times 10^{-7} \mathrm{~W} \mathrm{~kg}^{-1}\right)$, as shown on 21 November 2013 at $140 \mathrm{~m}$ depth (Fig. 10a). In Puyuhuapi Fjord turbulent kinetic energy dissipation between 20 and $180 \mathrm{~m}$ was weak $\left(10^{-10}\right.$ to $\left.10^{-7} \mathrm{~W} \mathrm{~kg}^{-1}\right)$
(Fig. 10c, e). The dissipation rates of turbulent kinetic energy are obtained by integrating the velocity shear spectrum at each respective depth bin up to the noise limit. The noise limit is determined by comparing the measured spectra to the theoretical Naysmyth spectra and determining where the measurements begin to deviate from theory. To display how the estimates of $\varepsilon$ were obtained at the Jacaf sill depth, the shear spectra are shown for VMP profiles collected at the Jacaf sill region (21 November 2013 at $140 \mathrm{~m}$ depth; Fig. 10b), and in Puyuhuapi Fjord on 22 November 2013 (at $140 \mathrm{~m}$ depth; Fig. 10d) and on 23 January 2014 (at $140 \mathrm{~m}$ depth; Fig. 10f).

In Puyuhuapi Fjord, the correlation between $\varepsilon$ and zooplankton $S_{\mathrm{v}}$ data (38 kHz, fixed station, January 2014) was high $\left(R^{2}=0.65\right.$, Fig. 11a). In the same campaign, the in situ macrozooplankton density $(>5 \mathrm{~mm}$ ) was also highly correlated with $\varepsilon$ values $\left(R^{2}=0.79\right.$ for $\varepsilon$ vs. siphonophores, $R^{2}=0.66$ for $\varepsilon$ vs. chaetognaths, and $R^{2}=0.77$ for $\varepsilon$ vs. euphausiids; Fig 11b-d). Unfortunately, VMP data were not collected in Jacaf Channel in wintertime. In order to confirm the relationship between $\varepsilon$ and various zooplankton species, additional turbulence measurements were collected in November 2013 along Jacaf sill (Fig. 12a). Results showed strong velocity shear in the horizontal velocities (Fig. 12b) accompanied by high $\varepsilon$ values $\left(10^{-7}\right.$ to $\left.10^{-5} \mathrm{~W} \mathrm{~kg}^{-1}\right)$. Maximum $\varepsilon$ was measured at the Jacaf-Puyuhuapi confluence $(10 \mathrm{~km}$ along transect) at $\sim 63 \mathrm{~m}$ depth where $\varepsilon=1.9 \times$ $10^{-5} \mathrm{~W} \mathrm{~kg}^{-1}$ (Fig. 12b; St. 164). The diapycnal eddy diffusivity $\left(K_{\rho}\right)$ was also high in the same area with values of $10^{-4}$ to $10^{-3} \mathrm{~m}^{2} \mathrm{~s}^{-1}$ (Fig. 12c).

\section{Discussion}

This study represents one of the first attempts to combine measurements of acoustics, stratified plankton sampling, microstructure profiles and standard hydrographic profiles to investigate both the vertical distribution patterns of macrozooplankton and why these patterns exist in northwest Patagonian fjords and other subantarctic latitudes. Three main findings resulted from this effort. First, DVM patterns of macrozooplankton became evident from all methodological approaches and at all study periods: May 2013, January 2014 and August 2014 (Figs. 3-5 and 7-9). Second, strong evidence arose showing macrozooplankton avoidance of hypoxic layers. And, third, a clear increment of macrozooplankton and fish aggregations around the Jacaf sill could be related to increased turbulence in this area.

\subsection{Diel vertical migration patterns}

Consistent evidence from multiple echo-sounder surveys, ADCP moorings and semi-continuous in situ zooplankton measurements supported the existence of major circadian displacements of macrozooplankton during night hours be- 

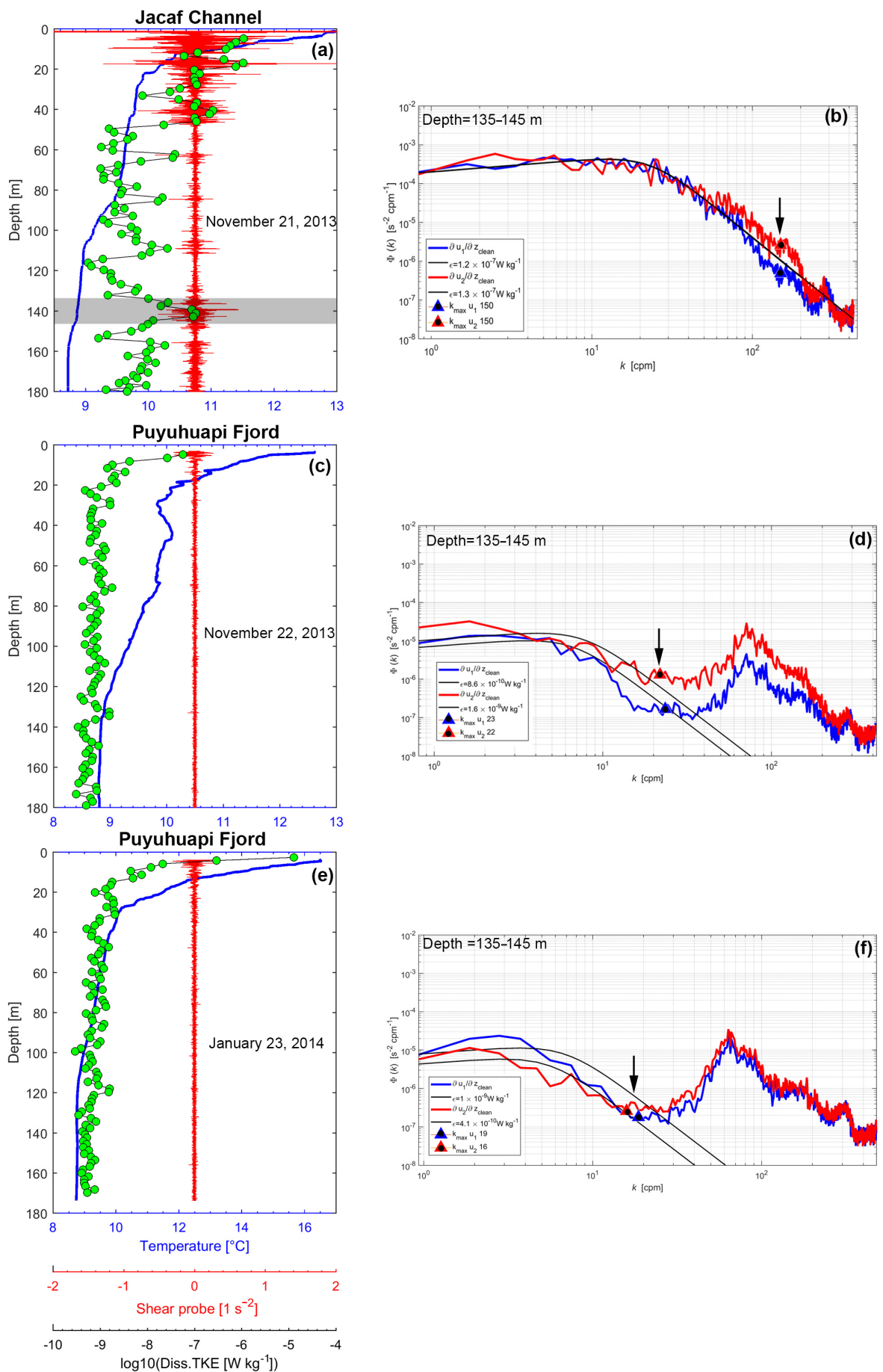

Figure 10. Profiles of water temperature (blue line), vertical shear (red line) and dissipation rate of turbulent kinetic energy (black line with green dots) obtained with the VMP-250 microprofiler at the depth of the Jacaf sill ( $\sim 140 \mathrm{~m}$ depth) in (a) Jacaf Channel on 21 November 2013 , (c) Puyuhuapi Fjord on 22 November 2013 and (e) in Puyuhuapi Fjord on 23 January 2014. (b, d, f) Representative spectra of velocity shear $(\partial u / \partial z)$ for shear probe 1 (blue line) and shear probe 2 (red line) in wave number space in Jacaf Channel on 21 November 2013, Puyuhuapi Fjord on 22 November 2013 and Puyuhuapi Fjord on 23 January 2014, respectively. The black line denotes the dimensional Nasmyth spectrum and the red and blue triangles the cut-off of maximum wave number $\left(k_{\max }\right)$ for each shear probe. The shear spectra were carried out in the same layer (135-145 m) for all turbulence profilers. 

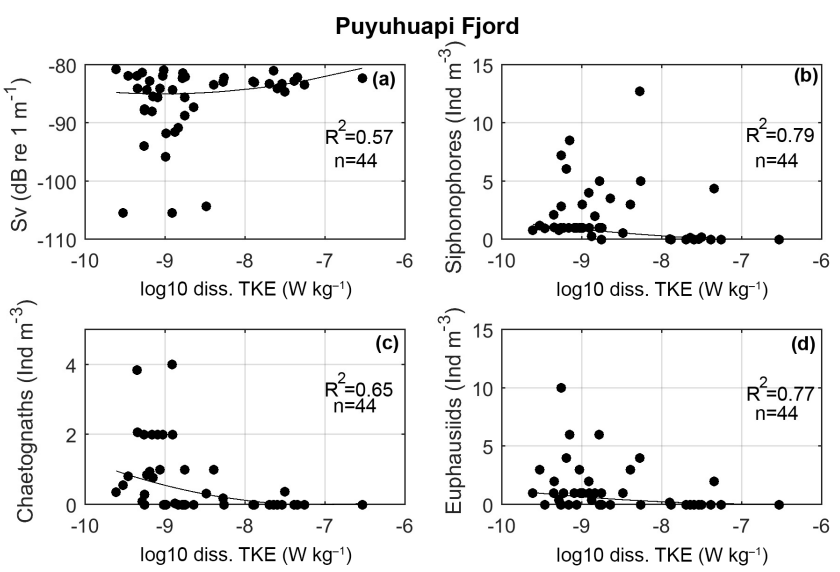

Figure 11. Scatter plots of dissipation rate of turbulent kinetic energy $(\varepsilon)$ and (a) volume backscattering strength $\left(S_{\mathrm{V}}\right)$ from $38 \mathrm{kHz}$ frequency and (b, c, d) the most abundance macrozooplankton species obtained in the in situ fixed stations carried out in Puyuhuapi Fjord during 22-24 January 2014.

tween mid-depth (20-120 m) and subsurface waters in our study area. Similar DVM patterns have been found in Reloncaví Fjord $\left(41.5^{\circ} \mathrm{S}\right)$, from 300 and $600 \mathrm{kHz}$ ADCP data, by Valle-Levinson et al. (2014) and Días-Astudillo et al. (2017) using a $75 \mathrm{kHz}$ acoustic device. Given a greater resolution, the later work was able to confirm that the DVM affected the whole water column of the fjord $(\sim 200 \mathrm{~m})$. These studies found the presence of euphausiids, decapods, mesopelagic shrimps, copepods and other groups in the Reloncaví Fjord in July and November 2006 (Valle-Levinson et al., 2014), as well as in July 2013 (Días-Astudillo et al., 2017). DVM is a common feature of many zooplankton groups, observed around the world using different ADCP and echosounder frequencies, e.g., at the Kattegat Channel (Buchholz et al., 1995), the northeast Atlantic (Heywood, 1996), the northwest coast of Baja California, Mexico (Robinson and Gómez-Gutiérrez, 1998), the northeastern Gulf of Mexico (Ressler, 2002), the Antarctic Peninsula (Zhou and Dorland, 2004), the Arabian Sea (Fielding et al., 2004), Funka Bay, Japan (Lee et al., 2004), south Georgia (USA), in the Atlantic sector of the Southern Ocean (Brierley et al., 2006) and Saanish Inlet, British Columbia, Canada (Sato et al., 2013). The scattering layers observed in these studies highlight the abundances of the major zooplankton species, represented by amphipods, euphausiids, siphonophores, chaetognaths, pteropods, crustaceans, small fish and gelatinous plankton. While most DVM patterns reported in these studies occurred between 0 and $\sim 300 \mathrm{~m}$ depth, the deepest DVM patters were observed in the North Atlantic Ocean, reaching depths $\sim 1600 \mathrm{~m}$ (Van Haren and Compton, 2013).

DVM patterns of zooplankton are expected to be associated with diel changes in visible light within the photic zone (from surface to $\sim 100 \mathrm{~m}$ ). Thus, the zooplankton can avoid predators during daytime hours and have safe-feeding con- ditions at night. While only small irradiance levels, $<10^{-7}$ times surface levels, can be detected beyond $600 \mathrm{~m}$ (Van Haren and Compton, 2013; Sato et al., 2013, 2016), zooplankton DVM can reach depths below $500 \mathrm{~m}$ (Van Haren and Compton, 2013). Moreover, zooplankton DVM occurs in Arctic fjords (e.g., the Kongsfjorden and Rijpfjorden fjords) even during the polar night, suggesting a high sensitivity to very low levels of solar and/or lunar light (Berge et al., 2009). Since both Puyuhuapi Fjord and Jacaf Channel are not deeper than $300 \mathrm{~m}$, enough light should reach the bottom layer and stimulate zooplankton DVM across the whole water column. However, our results show that zooplankton DVM (and distribution as discussed in the next section) was limited by the hypoxic boundary layer present in the Puyuhuapi Channel ( $\sim 100 \mathrm{~m}$; Fig. 5), providing indirect support to the idea that hypoxia may limit DVM in poorly ventilated Patagonian fjords and elsewhere (Ekau et al., 2010; Mass et al., 2014; Hauss et al., 2016; Seibel et al., 2016).

\subsection{Macrozooplankton avoidance of hypoxic waters}

In Puyuhuapi Fjord, hypoxic conditions have been reported below $\sim 100 \mathrm{~m}$ depth, all year round (Schneider et al., 2014; Silva and Vargas, 2014), with sporadic deep ventilation events that increase the DO concentration from 1.4 to $2.8 \mathrm{~mL} \mathrm{~L}^{-1}$ (Pérez-Santos, 2017). These pervasive hypoxic conditions are not common in all Patagonian fjords. For instance, seasonal hydrographic data from Reloncaví Fjord showed well-ventilated conditions along the fjord, with deep, near-bottom DO values between 3 and $3.5 \mathrm{mLL}^{-1}$ (Castillo et al., 2016).

In the current study, acoustic measurements revealed that most biological backscattering ( $S_{\mathrm{V}}$ data) occurred above the hypoxic boundary layer (Fig. 5), which acted as a barrier to DVM and macrozooplankton distribution throughout the year. Similar findings were reported in Oslofjord, Norway, where hypoxic conditions dominated the water column beneath $\sim 60 \mathrm{~m}$ depth, and no fish or krill were observed below this depth (Røstad and Kaartvedt, 2013). Moreover, in the eastern South Pacific OMZ, it has been previously reported that a number of copepod species and life-stages avoid hypoxic waters (Castro et al., 1993; Escribano et al., 2009), as well as for most gelatinous zooplankton groups (Pages et al., 2001; Giesecke and Gonzalez, 2005; Escribano et al., 2009). In the same OMZ region, but further north in Peruvian waters, two diurnal scattering layers were observed, one over the OMZ and another, mainly composed of adult euphausiids, in the core of the OMZ (Ballón et al., 2011). Euphausiids, salps and myctophid fish were also observed in the core of the eastern tropical North Pacific OMZ (Mass et al., 2014). Seibel et al. (2016) reported Euphausia eximia and Nematoscelis gracilis tolerance to hypoxic water and suggest this tolerance would enable these species to reduce their energy expenditure by at least $50 \%$ during their daytime migration. 


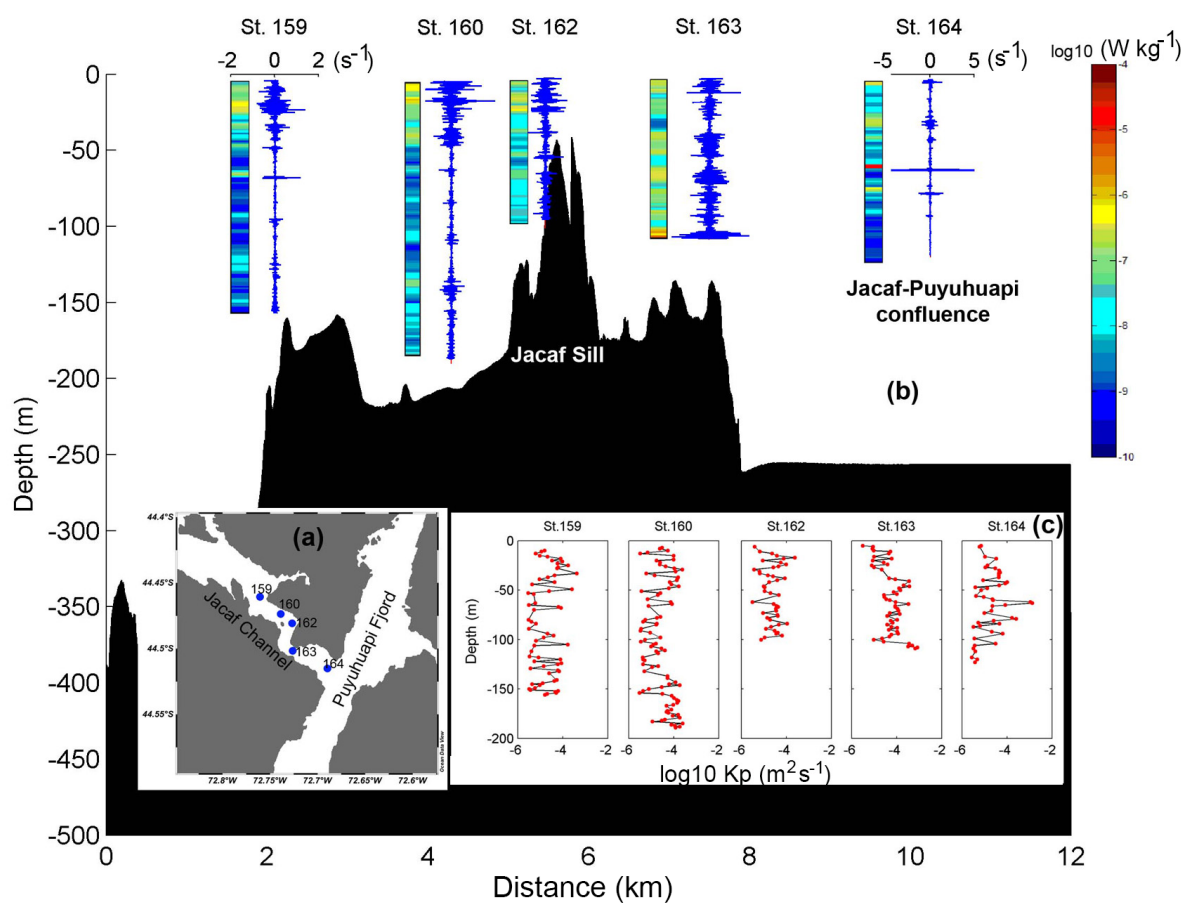

Figure 12. (a) Microstructure profile locations along Jacaf Channel and sill using VMP-250 in November 2013. (b) The color bar showed the dissipation rate of turbulent kinetic energy $(\varepsilon)$ and the blue lines depict the velocity shear at each station location along Jacaf Channel (as shown in (a)). The horizontal scale (-2 to $2 \mathrm{~s}^{-1}$ ) applied to profiles at stations 160, 162 and 163. Station 164 is located at the confluence of Jacaf Channel and Puyuhuapi Fjord $(10.5 \mathrm{~km})$. (c) The diapycnal eddy diffusivity profiles $\left(K_{\mathrm{p}}\right)$, obtained at each station shown in $(\mathbf{a})$.

The highest $S_{\mathrm{v}}$ values observed in Puyuhuapi Fjord occurred at DO concentrations between 2 and $5 \mathrm{mLL}^{-1}$, while in Jacaf Channel between 3 to $6 \mathrm{mLL}^{-1}$. DO values of 3.5 and $4.5 \mathrm{mLL}^{-1}$ seemed to represent appropriate conditions for most macrozooplankton species in Puyuhuapi Fjord and Jacaf Channel, respectively, which are similar to the values indicated by Ekau et al. (2010) for zooplankton. Our results also showed that macrozooplankton preferred oceanic waters with salinity values $>31 \mathrm{~g} \mathrm{~kg}^{-1}$, and temperatures between 8 and $10^{\circ} \mathrm{C}$ (Figs. 4 and 9). Nonetheless, it must be considered that these preference values were estimated from observational data and limited sampling rather than from controlled experiments.

Vertical overlapping observed between fish and macrozooplankton abundances suggests that prey-predator interactions might be enhanced under hypoxic conditions. Pollution and climate change are continually expanding the extent of hypoxic waters around the world, both in coastal waters and open oceans (Breitburg et al., 2018). While the links between recent anthropogenic perturbations, such as the salmon aquaculture expansion and hypoxia in Patagonian fjords, are still under debate, it is important to keep this potential impact upon habitat reductions and enhanced prey-predator interactions under consideration as it might cause changes in zooplankton groups' distributions and abundance, particularly those that do not tolerate low DO concentrations.
The fact that some biological backscattering occurred within the hypoxic layer in our study indicates that hypoxia does not affect all macrozooplankton species equally and that some of them can inhabit this deeper layer, e.g., euphausiid species (Mass et al., 2014; Seibel et al., 2016). Hypoxiatolerant species residing below and within minimum DO layers have been reported, for example, further north along the Chilean coast during the upwelling season, leading support to the hypotheses on predation evasion and horizontal transport aiming to explain such behavior (Castro et al., 2007). Within this context, Euphausia pacifica has been reported to exhibit the highest abundance of zooplankton species present in hypoxic waters in Hood Canal, USA (Sato et al., 2016). Other euphausiids have also been reported to be present in other hypoxic systems in Chile (Escribano et al., 2009; Gonzalez et al., 2016). It has been shown that Euphasia vallentini is a dominant euphausiid species known to carry out extensive vertical migrations in Patagonian fjords, hence we speculate it might be one of the species occurring in the less oxygenated waters of our study. Unfortunately, due to sampling gear restrictions, we were unable to sample the hypoxic layer, nor to firmly identify the species occurring at this depth. Therefore, future research will be necessary to understand the relationship of the deep, yet scarce, macrozooplankton within the hypoxic waters in Puyuhuapi Fjord. As vertical mixing is a mechanism that could reduce the presence of 


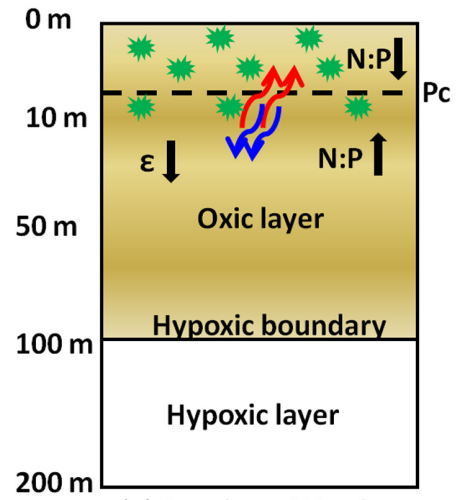

(a) Puyuhuapi Fjord

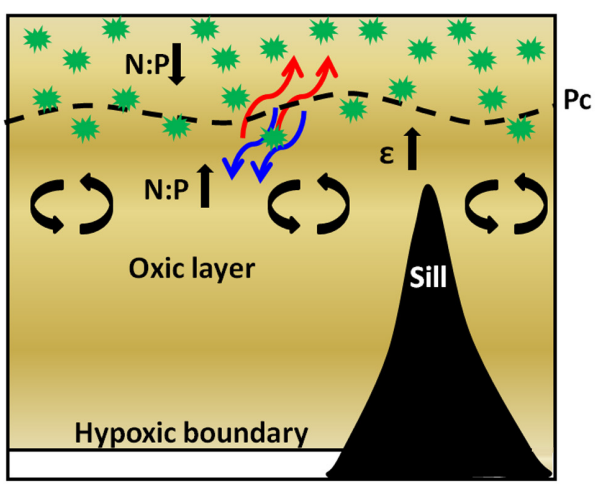

(b) Jacaf Channel

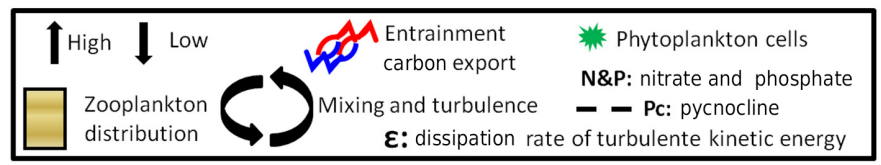

Figure 13. Conceptual model to show the oceanographic processes that contribute to the distribution and aggregation of zooplankton in (a) Puyuhuapi Fjord and (b) Jacaf Channel.

hypoxic zones in fjords, values of turbulent kinetic energy dissipation were compared to the depth strata of macrozooplankton.

\subsection{Turbulent mixing at the fjord sill}

Patagonian fjords and channels cover an area of $\sim 240000 \mathrm{~km}^{2}$ and feature a complex marine topography, including submarine sills and channel constrictions (Iriarte et al., 2014; Inall and Gillibrand, 2010). Bernoulli aspiration, internal hydraulic jumps and intense tidal mixing are all processes that can be found near a fjord sill (Farmer and Freeland, 1983; Klymark and Gregg, 2003; Inall and Gillibrand, 2010; Whitney et al., 2014). Our data showed elevated values of turbulent kinetic energy dissipation in Jacaf Channel $\left(\varepsilon=10^{-5} \mathrm{~W} \mathrm{~kg}^{-1}\right.$ and $\left.K_{\rho}=10^{-3} \mathrm{~m}^{2} \mathrm{~s}^{-1}\right)$ near the sill from 0 to $60 \mathrm{~m}$ depth. These values are similar to those observed at the sill of Knight Inlet in Canada (Klymark and Gregg, 2003). Lower $\varepsilon$ values were found in Puyuhuapi Fjord (Fig. 10). The elevated vertical mixing (high $K_{\rho}$ ) in Jacaf Channel is probably due to the barotropic tide interacting with the submarine sill (Schneider et al., 2014; Figs. 10, 12 and Table 2). This was also observed in Martinez Channel (Pérez-Santos et al., 2014), central Patagonia, where semidiurnal internal tides were found to dominate the estuarine dynamics (Ross et al., 2014). This region is highly influenced by the Baker River, whose discharge enhances stratification and introduces suspended solids that subsequently limit productivity in the water column (González et al., 2010, 2013; Daneri et al., 2012).

The evident aggregation of macrozooplankton and fish found near Jacaf sill (within $\sim 1 \mathrm{~km}$ ) matches the area exhibiting the highest $\varepsilon$ values $\left(\sim 10^{-5} \mathrm{~W} \mathrm{~kg}^{-1}\right.$; Fig. 12). Thin
$(2-5 \mathrm{~m})$ and thick $(10-50 \mathrm{~m})$ regions of enhanced vertical shear measured directly with the VMP-250 microstructure profiler contribute to vertical mixing. Subsequently this enhances the exchange between the subsurface, rich nutrient layer (Fig. 2) and the photic layer, leading to increased phytoplankton productivity (Montero et al., 2017a, b), as shown in the conceptual model of Fig. 13. Thus, the acoustic and turbulence measurements collected near Jacaf sill promote the importance of a sill in influencing the vertical distribution of oxygen, macrozooplankton and fish on both sides of the sill.

A summary of the processes that can contribute to macrozooplankton vertical distribution and aggregation in Puyuhuapi Fjord and Jacaf Channel are presented in a Fig. 13. In Puyuhuapi Fjord, at $100 \mathrm{~m}$ depth a high nutrient and high production layer (Daneri et al., 2012; Montero et al., 2017a, b) is separated from a hypoxic layer below, which limits species distribution and lacks significant aggregations of zooplankton. Above the hypoxic waters, turbulent mixing enhances contact between macrozooplankton predators and their prey (Visser et al., 2009). In Jacaf Channel, the hypoxic layer occurs deeper in the water column than in Puyuhuapi Fjord, which stretches the vertical distribution of macrozooplankton to a deeper range. Turbulent mixing also increases primary and secondary production, through enhanced nutrient availability and favors encounters of macrozooplankton with potential prey, increasing growth and survival rates (Visser and Stips, 2002; MacCready et al., 2002; Klymak and Gregg, 2004; Lee et al., 2005; Visser et al., 2009; Whitney et al., 2014). 


\subsection{Other findings and considerations}

Results showed similar groups of macrozooplankton $(>5 \mathrm{~mm}$ ) in Puyuhuapi Fjord and Jacaf Channel: euphausiids, chaetognaths, medusae and siphonophores during summer (January 2014) and winter (winter 2014). However, euphausiids were not observed in fall 2013, which was an unexpected result which deserves further confirmation and analysis. In contrast, fall 2013 sampling presented the highest acoustic abundances within the time series (Fig. 3). The elevated accumulation of macrozooplankton species around the sill may impose a significant modification in the amount and quality of carbon exported to deeper waters in particular zones of the fjords. Future studies on carbon flux quantification in fjords should incorporate sill regions to test this hypothesis, in order to improve ocean pumping assessments in the context of climate change and variability.

\section{Conclusions}

This paper was aimed to determine how hypoxic conditions affect the vertical distribution of macrozooplankton in fjords and to assess how vertical mixing relates to abundances of macrozooplankton at fjord sills. Results showed that the hypoxic layer in Patagonian fjords limits DVM and overall distribution of macrozooplankton to the upper $\sim 100 \mathrm{~m}$ of the water column, reducing the habitat of these species. The hypoxic zones were found away from underwater sills or areas that would experience enhanced turbulence. When assessing the abundance of macrozooplankton in conjunction with turbulent kinetic energy dissipation near a submarine sill it was found that elevated turbulence generated by the barotropic tide interacting with the sharp bathymetric feature enhanced vertical mixing, deepened the hypoxic layer and injected nutrients. In addition, macrozooplankton were found in higher densities and extended deeper in the water column around the submarine sills. This is thought to be due to an increase in primary production that would result from the effects of elevated vertical mixing.

Data availability. All data sets used in this manuscript can be request from the corresponding author.

Author contributions. IPS: study design, collection and analysis of physical oceanographic and acoustic data, and manuscript leader. LR and NM: collection and analysis of physical oceanographic and acoustic data, and manuscript revision. LC and EE: study design, collection and analysis of zooplankton data, and manuscript revision. MG, EN, LC and NA: analysis of acoustic data and manuscript revision. MC: analysis of tidal data. GD: study design, collection of nutrient data and manuscript revision. All authors contributed to the writing of the manuscript.
Competing interests. The authors declare that they have no conflict of interest.

Acknowledgements. The ADCP data were collected as part of the FONDECYT grant 3120038 and 11140161 by Ivan PerezSantos and the help of Wolfgang Schneider's research group. Financial support was also provided by Centro Copas Sur Austral AFB170006. We thank Arnoldo Valle-Levinson for motivating the acoustic study of zooplankton in Chilean Patagonia. We also thank Luis Cubillos and Billy Ernst for providing the scientific echo sounder and Cristian Parra and Hernán Rebolledo for administering the scientific echo-sounder sampling. Leonardo Castro was also financed by Centro de Investigaciones de Altas Latitudes (IDEAL). We thank Juan Ramón Velasquez and Oscar Pizarro's research group for their assistance in the ADCP 1, 2 and 3 moorings and Adolfo Mesa, Aldo Balba and Eduardo Escalona for conducting most of the zooplankton sampling. Giovanni Daneri is funded by FONDECYT grant 1131063. Manuel Castillo is funded by FONDECYT grant 11160500.

Edited by: Markus Meier

Reviewed by: five anonymous referees

\section{References}

Ariza, A., Landeira, J. M., Escánez, A., Wienerroither, R., Aguilar de Soto, N., Røstad, A., Kaartvedt, S., and Hernández-León, S.: Vertical distribution, composition and migratory patterns of acoustic scattering layers in the Canary Islands, J. Mar. Syst, 157, 82-91, 2016

Ayón, P., Criales-Hernandez, M. I., Schwamborn, R., and Hirche, H. J.: Zooplankton research off Peru: a review, Prog. Oceanogr., 79, 238-255, 2008.

Ballón, M.: Acoustic study of macrozooplankton off Peru: biomass estimation, spatial patterns, impact of physical forcing and effect on forage fish distribution, Thesis, Universite Montpellier II, 205 pp., Montpellier, France, 2010.

Ballón, M., Bertrand, A., Lebourges-Dhaussy, A., Gutiérrez, M., Ayón, P., Grados, D., and Gerlotto, F.: Is there enough zooplankton to feed forage fish populations off Peru? An acoustic (positive) answer, Prog. Oceanogr., 91, 360-381, 2011.

Basedow, S. L., Eliane, K., Tverberg, V., and Spindler, M.: Advection of zooplankton in an Arctic fjord (Kongsfjorden, Svalbard), Estuar. Coast. Shelf S., 60, 113-124, 2004.

Bearman, G.: Waves, tides and shallow water processes, Butterworth-Heinemann, Oxford, 187 pp., 1989.

Berge, J., Cottier, F., Last, K., Varpe, Ø., Leu, E., Søreide, J., Eiane, K., Falk-Petersen, S., Willis, K., Nygård, H., Vogedes, D., Griffiths, C., Johnsen, G., Lorentzen, D., and Brierley, A.: Diel vertical migration of Arctic zooplankton during the polar night, Biol. Lett., 5 69-72, 2009.

Buchholz, F., Buchholz, C., Reppin, J., and Fischer, J.: Diel vertical migrations of Meganyctiphanes norvegica in the Kattegat: Comparison of net catches and measurements with Acoustic Doppler Current Profilers, Helgolander Meeresun., 49, 849-866, 1995.

Breitburg, D., Levin, L. A., Oschlies, A., Grégoire, M.,. Chavez, F. P., Conley, D. J., Garçon, V., Gilbert, D., Gutiérrez, D., Isensee, 
K., Jacinto, G. S., Limburg, K. E., Montes, I., Naqvi, S. W., Pitcher, G. C., Rabalais, N. N., Roman, M. R., Rose, K. A., Seibel, B. A., Telszewski, M., Yasuhara, M., and Zhang, J.: : Declining oxygen in the global ocean and coastal waters, Science, 359, 1-11, 2018.

Brierley, A., Saunders, R. A., Bone, D. G., Murphy, E. J., Enderlein, P., Conti, S. G., and Demer, D. A.: Use of moored acoustic instruments to measure short-term variability in abundance of Antarctic krill, Limnol. Oceanogr.-Meth., 4, 18-29, 2006.

Cade, D. E. and Benoit-Bird, K. J.: Depths, migration rates and environmental associations of acoustic scattering layers in the Gulf of California, Deep-Sea Res. Pt. I, 102, 78-89, 2015.

Castillo, M. I., Cifuentes, U., Pizarro, O., Djurfeldt, L., and Caceres, M.: Seasonal hydrography and surface outflow in a fjord with a deep sill: the Reloncaví fjord, Chile, Ocean Sci., 12, 533-544, https://doi.org/10.5194/os-12-533-2016, 2016.

Castro, L. R., Bernal, P. A., and Troncoso, V. A.: Coastal intrusion of copepods: mechanisms and consequences in the population biology of Rhincalanus nasutus, J. Plankton Res., 15, 501-515, 1993.

Castro, L. R. and Troncoso, V. A.: Fine-scale vertical distribution of coastal and offshore copepods in the Golfo de Arauco, central Chile, during the upwelling season, Prog. Oceanogr., 75, 486500, 2007

Castro, L. R., Caceres, M. A., Silva, N., Muñoz, M. I., León, R., Landaeta, M. F., and Soto Mendoza, S.: Short-term variations in mesozooplankton, ichthyoplankton, and nutrients associated with semi-diurnal tides in a Patagonian Gulf, Cont. Shelf Res., 31, 282-292, 2014.

Cloern, J.: Tidal stirring and phytoplankton bloom dynamics in an estuary, J. Mar. Res., 49, 203-221, 1991.

Cuypers, Y., Bouruet-Aubertot, P., Marec, C., and Fuda, J.-L.: Characterization of turbulence from a fine-scale parameterization and microstructure measurements in the Mediterranean Sea during the BOUM experiment, Biogeosciences, 9, 3131-3149, https://doi.org/10.5194/bg-9-3131-2012, 2012.

Daneri, G., Montero, P., Lizárraga, L., Torres, R., Iriarte, J. L., Jacob, B., González, H. E., and Tapia, F. J.: Primary Productivity and heterotrophic activity in an enclosed marine area of central Patagonia (Puyuhuapi channel; $44^{\circ} \mathrm{S}, 73^{\circ} \mathrm{W}$ ), Biogeosciences Discuss., 9, 5929-5968, https://doi.org/10.5194/bgd-95929-2012, 2012.

Díaz, R. J.: Overview of hypoxia around the world, J. Environ. Qual., 30, 275-281, 2001

Díaz-Astudillo, M., Cáceres, M., and Landaeta, M.: Zooplankton structure and vertical migration: Using acoustics and biomass to compare stratified and mixed fjord systems, Cont. Shelf Res., 148, 208-218, 2017.

Dyer, K. R.: Estuaries: A physical introduction, John Wiley \& Sons, West Sussex, England, 1997.

Ekau, W., Auel, H., Pörtner, H.-O., and Gilbert, D.: Impacts of hypoxia on the structure and processes in pelagic communities (zooplankton, macro-invertebrates and fish), Biogeosciences, 7, 1669-1699, https://doi.org/10.5194/bg-7-1669-2010, 2010.

Escribano, R., Hidalgo, P., and Krautz, C.: Zooplankton associated with the oxygen minimum zone system in the northern upwelling region of Chile during March 2000, Deep-Sea Res. Pt. II, 56, 1083-1094, 2009.
Farmer, D. M. and Freeland, H. J.: The physical oceanography of fjords, Prog. Oceanogr., 12, 147-194, 1983.

Fielding, S., Griffiths, G., and Roe, H. S. J.: The biological validation of ADCP acoustic backscatter through direct comparison with net samples and model predictions based on acousticscattering models, J. Mar. Sci., 61, 184-200, 2004.

Foreman, M. G. G.: Manual for Tidal Heights Analysis and Prediction, Pacific Marine Science Report 77-10, Sidney, Canada, 1977.

Foreman, M. G. G.: Manual for Tidal Currents Analysis and Prediction, Pacific Marine Science Report 78-6, Sidney, Canada, 1978

Foote, K. G., Knudsen, H. P., Vestnes, G., MacLennan, D. N., and Simmonds, E. J.: Calibration of acoustic instruments for fish density estimation: a practical guide. ICES cooperative research report $\mathrm{N}^{\circ} 144$, International Council for the Exploration of the Sea, Copenhaguen, Denmark, 1987.

Fuenzalida, R., Schneider, W., Garcés-Vargas, J., Bravo, L., and Lange, C.: Vertical and horizontal extension of the oxygen mínimum zone in the eastern South Pacific Ocean, Deep-Sea Res. Pt. II, 56, 1027-1038, 2009.

Gattuso, J., Frankingnoulle, M., and Wollast, R.: Carbon and carbonate metabolism in coastal aquatic ecosystems, Annu. Rev. Ecol. Syst., 29, 405-434, 1998.

Giesecke, R. and González, H. E.: Feeding of Sagitta enflata and vertical distribution of chaetognaths in relation to low oxygen concentrations, J. Plankton Res., 26, 475-486, 2005.

González, H. E., Calderon, M. J., Castro, L., Clement, A., Cuevas, L. A., Daneri, G., Iriarte, J. L., Lizárraga, L., Martinez, R., Menschel, E., Silva, N., Carrasco, C., Valenzuela, C., Vargas, C. A., and Molinet, C.: Primary Production and plankton dynamics in the Reloncavi Fjord and the Interior Sea of Chiloe, Northern Patagonia, Chile, Mar. Ecol. Prog. Ser., 402, 13-30, 2010.

González, H. E., Castro, L., Daneri, G., Iriarte, J. L., Silva, N., Vargas, C., Giesecke, R., and Sánchez, N.: Seasonal plankton variability in Chilean Patagonia Fjords: carbon flow through the pelagic foodweb of the Aysen Fjord and plankton dynamics in the Moraleda Channel basin, Cont. Shelf Res. 31, 225-243, 2011.

González, H. E., Castro, L. R., Daneri, G., Iriarte, J. L., Silva, N., Tapia, F., Teca, E., and Vargas, C. A.: Land-ocean gradient in haline stratification and its effects on plankton dynamics and trophic carbon fluxes in Chilean Patagonian fjords $\left(47-50^{\circ} \mathrm{S}\right)$, Prog. Oceanogr., 119, 32-47, 2013.

González, H. E, Graeve, M., Kattner, G., Silva, N., Castro, L., Iriarte, J. L., Osmán, L., Daneri, G., and Vargas, C. A.: Carbon flow through the pelagic food web in southern Chilean Patagonia: relevance of Euphausia vallentini as key species, Mar. Ecol. Prog. Ser., 557, 91-110, 2016.

Godin, G.: The Analysis of Tides, University of Toronto Press, Toronto, 1972.

Govani, J. J., Hoss, D. E., and Colby, D. R.: The spatial distribution of larval fishes about the Mississippi River plume, Limnol. Oceanogr., 34, 178-187, 1989.

Greene, C. H. and Peter, H. W.: Bioacoustical oceanography: New tools for zooplankton and micronekton research in the 1990s, Oceanography, 3, 12-17, 1990.

Van Haren, H. and Compton, T. J.: Diel Vertical Migration in Deep Sea Plankton Is Finely Tuned to Latitudinal and Seasonal Day Length, PLoS ONE, 8, e64435, https://doi.org/10.1371/journal.pone.0064435, 2013. 
Haury, L. R., Yamazaki, H., and Itsweire, E. C.: Effects of turbulent shear flow on zooplankton distribution, Deep-Sea Res., 37, 447$461,1990$.

Hauss, H., Christiansen, S., Schütte, F., Kiko, R., Edvam Lima, M., Rodrigues, E., Karstensen, J., Löscher, C. R., Körtzinger, A., and Fiedler, B.: Dead zone or oasis in the open ocean? Zooplankton distribution and migration in low-oxygen modewater eddies, Biogeosciences, 13, 1977-1989, https://doi.org/10.5194/bg-131977-2016, 2016.

Heywood, K.: Diel vertical migration of zooplankton in the Northeast Atlantic, J. Plankton Res., 18, 163-184, 1996.

Horne, J. K. and Jech, J. M.: Multi-frequency estimates of fish abundance: constraints of rather high frequencies, J. Marine Sci., 56, 184-199, 1999.

Holliday, D. V. and Pieper, R. E.: Bioacoustical oceanography at high frequencies, J. Marine Sci., 52, 279-296, 1995.

Inall, M. E. and Gillibrand, P. A.: The physics of mid-latitude fjords: a review, Geological Society, Special Publications, London, UK, 344, 17-33, 2010.

IOC, SCOR and IAPSO: The international thermodynamic equation of seawater - 2010: Calculation and use of thermodynamic properties, Intergovernmental Oceanographic Commission, Manuals and Guides No. 56, UNESCO, 196 pp., available at: http://www. teos-10.org/ (last access: 2 October 2018), 2010.

Iriarte, J. L., Pantoja, S., and Daneri, G.: Oceanographic Processes in Chilean Fjords of Patagonia: From small to large-scale studies, Prog. Oceanogr., 129, Part A, 1-7, https://doi.org/10.1016/j.pocean.2014.10.004, 2014

Kloser, R. J., Ryan, T., Sakov, P., Willliams, A., and Koslow, J. A.: Species identification in deep water using multiple acoustic frequencies, Can. J. Fish Aquat. Sci., 59, 1065-1077, 2016.

Klymak, J. M. and Gregg, M. C.: Tidally Generated Turbulence over the Knight Inlet Sill, American Meteorological Society, https://doi.org/10.1175/15200485(2004)034<1135:TGTOTK>2.0.CO;2, 1-17, 2004.

Koseff, J., Holen, J., Monismith, S., and Cloern, J.: Coupled effects of vertical mixing and benthic grazing on phytoplankton populations in shallow, turbid estuaries, J. Mar. Res., 51, 843-868, 1993.

Landaeta, M., Martínez, R., Bustos, C., and Castro L.: Distribution of microplankton and fish larvae related to sharp clines in a Patagonian fjord, Rev. Biol. Mar. Oceanog., 48, 401-407, 2013.

Lee, K., Mukai, T., Kang, D., and Iida, K.: Application of acoustic Doppler current profiler combined with a scientific echo-sounder for krill Euphausia pacifica density estimation, Fisheries Sci., 70, 1051-1060, 2004.

Lee, O., Nash, R. D. M., and Danilowicz, B. S.: Smallscale spatio-temporal variability in ichthyoplankton and zooplankton distribution in relation to a tidal-mixing front in the Irish Sea, J. Mar. Sci., 62, 1021-1036, https://doi.org/10.1016/j.icesjms.2005.04.016, 2005.

Lewis, D. and Pedley, T.: The Infuence of Turbulence on Plankton Predation Strategies, J. Theor. Biol., 210, 347-365, 2001.

Logerwell, E. A. and Wilson, C.: Species discrimination of fish using frequencydependent acoustic backscatter, J. Marine Sci., 61, 1004-1013, 2004.

Lough, R. G. and Manning, J. P.: Tidal-front entrainment and retention of fish larvae on the southern flank of Georges Bank, DeepSea Res., 48, Suppl. 2, 631-644, 2001.
MacCready, P., Hetland, R., and Geyer, R.: Long-term isohaline salt balance in an estuary, Cont. Shelf Res., 22, 1591-1601, 2002.

Maas, A. M., Frazar, S. L., Outram, D. M., Seibel, B. A., and Wishner, K. F.: Fine-scale vertical distribution of macroplankton andmicronekton in the Eastern Tropical North Pacific inassociation with an oxygen minimum zone, J. Plankton Res., 36, 1557-1575, 2014.

Mair, A., Fernandes, P., Lebourges-Dhaussy, A., and Brierley, A.: An investigation into the zooplankton composition of a prominent 38-khz scattering layer in the North Sea, J. Plankton Res., 27, 623-633, 2005.

Meerhoff, E., Castro, L., and Tapia, F.: Influence of freshwater discharges and tides on the abundance and distribution of larval and juvenile Munida gregaria in then Baker river estuary, Chilean Patagonia, Cont. Shelf Res., 61-62, 1-11, 2013.

Meerhoff, E., Tapia, F. J., Sobarzo, M., and Castro, L.: Influence of estuarine and secondary circulation on crustacean larval fluxes: a case study from a Patagonian fjord, J. Plankton Res., 37, 168182, https://doi.org/10.1093/plankt/fbu106, 2015.

Montero, P., Pérez-Santos, I., Daneri, G., Gutiérrez, M., Igor, G., Seguel, R., Crawford, D., and Duncan, P.: A winter dinoflagellate bloom drives high rates of primary production in a Patagonian fjord ecosystem, Estuar. Coast. Shelf S., 199, 105-116, 2017a.

Montero, P., Daneri, G., Tapia, F., Iriarte, J. L., and Crawford, D.: Diatom blooms and primary production in a channel ecosystem of central Patagonia, Lat. Am. J. Aquat. Res., 45, 999-1016, $2017 b$.

Mosteiro, A., Fernandes, P. G., Armstrong, F., and Greenstreet, S. P. R.: A Dual Frequency Algorithm for the Identification of Sandeel School Echotraces, ICES Document CM 2004/R: 12, 13 pp., 2004.

Munk, P., Wright, P. J., and Pihl, N. J.: Distribution of the early larval stages of Cod, Plaice and Lesser Sandeel across haline fronts in the North Sea, Estuar. Coast. Shelf S., 55, 139-149, 2002.

North, E. W. and Houde, E. D.: Retention of white perch and striped bass larvae: biological-physical interactions in Chesapeake Bay estuarine turbidity maximum, Estuaries, 24, 756-769, 2001.

North, E. W. and Houde, E. D.: Distribution and transport of bay anchovy (Anchoa mitchilli) eggs and larvae in Chesapeake Bay, Estuar. Coast. Shelf S., 60, 409-429, 2004.

Osborn, T. R.: Estimates of the local rate of vertical diffusion from dissipation measurements, J. Phys. Oceanogr., 10, 83-89, 1980.

Oviatt, C. A.: Effects of different mixing schedules on phytoplankton, zooplankton and nutrients in marine microcosms, Mar. Ecol. Prog. Ser., 4, 57-67, 1981.

Pagés, F., González, H. E., Ramon, M., Sobarzo, M., and Gili, J. M.: Gelatinous zooplankton assemblages associated with wáter masses in the Humboldt Current System, and potential predatory impact by Bassia bassensis (Siphonophora; Calycophorae), Mar. Ecol. Prog. Ser., 210, 13-24, 2001.

Palma, S.: Zooplankton distribution and abundance in the austral Chilean channels and fjords. Progress in the oceanographic knowledge of Chilean inner waters, from Puerto Montt to Cape Horn, Comité Oceanográfico Nacional - Pontificia Universidad Católica de Valparaíso, Valparaíso, Chile, 107-113, available at: http://www.cona.cl/ (last access: 2 October 2018), 2008.

Paulmier, A. and Ruiz-Pino, D.: Oxygen minimum zones (OMZs) in the modern ocean, Prog. Oceanogr., 80, 113-128, 2009. 
Pawlowicz, R., Beardsley, B., and Lentz, S.: Classical tidal harmonic analysis including error estimates in MATLAB using T_TIDE, Comput. Geosci., 28, 929-937, 2002.

Pantoja, S., Iriarte, L., and Daneri, G.: Oceanography of the Chilean Patagonia, Cont. Shelf Res., 31, 149-153, 2011.

Pérez-Santos, I., Garcés-Vargas, J., Schneider, W., Ross, L., Parra, S., and Valle-Levinson, A.: Double-diffusive layering and mixing in Patagonia fjords, Prog. Oceanogr., 129, 35-49, 2014.

Pérez-Santos, I.: Deep ventilation event during fall and winter of 2015 in Puyuhuapi fjord (44.6 S), Lajar, 45, 223-225, 2017.

Peters, H. and Bokhorst, R.: Microstructure observations of turbulent mixing in a partially mixed estuary. Part II: Salt flux and stress, J. Phys. Oceanogr., 31, 1105-1119, 2001.

Ressler, P. H.: Acoustic backscatter measurements with a $153 \mathrm{kHz}$ ADCP in the northeastern Gulf of Mexico: determination of dominant zooplankton and micronekton scatterers, Deep-Sea Res. Pt. I, 49, 2035-2051, 2002.

Rodriguez, J. M., Hernandez-Leon, S., and Barton, E. D.: Mesoscale distribution of fish larvae in relation to an upwelling filament off northwest Africa, Deep-Sea Res. Pt. I, 46, 19691984, 1999.

Robinson, C. and Gómez-Gutiérrez, J.: Daily vertical migration of dense deep scattering layers to the shelf-break along the northwest coast of Baja California, Mexico, J. Plankton Res., 20, 1679-1697, 1998.

Ross, L., Pérez-Santos, I., Valle-levinson, A., and Schneider, W.: Semidiurnal internal tides in a Patagonian fjord, Prog. Oceanogr., 129, 19-34, 2014.

Røstad, A. and Kaartvedt, S.: Seasonal and diel patterns in sedimentary flux of krill fecal pellets recorded by an echo-sounder, Limnol. Oceanogr., 58, 1985-1997, 2013.

Sato, M.: Variability in Diel Vertical Migration of Zooplankton and Physical Properties in Saanich Inlet, British Columbia, a dissertation submitted in partial fulfillment of the requirements for the degree of doctor of philosophy in the School of Earth and Ocean Sciences, University of Victoria, Canada, 2013.

Sato, M., Horne, J., Parker-Stetter, S., Essington, T., Keister, J., Moriarty, P., Li, L., and Newton, J.: Impacts of moderate hypoxia on fish and zooplankton prey distributions in a coastal fjord, Mar. Ecol. Prog. Ser., 560, 57-72, 2016.

Seibel, B. A., Schneider, J. L., Kaartvedt, S., Wishner, K. F., and Daly, K. L.: Hypoxia Tolerance and Metabolic Suppression in Oxygen Minimum Zone Euphausiids: Implications for Ocean Deoxygenation and Biogeochemical Cycles, Integr. Comp. Biol., $56,510-523,2016$.
Shih, L. H., Koseff, J. R., Ivey, G. N., and Ferziger, J.: Parameterization of turbulent fluxes and scales using homogeneous sheared stably stratified turbulence simulations, J. Fluid Mech., 525, 193 214, 2005.

Silva, N. and Calvete, C.: Physical and chemical oceanographic features of southern Chilean inlets between Penas Gulf and Magellan Strait (Cimar-Fiordo 2 cruise), Ciencias y Tecnología del Mar, 25, 23-88, 2002.

Silva, N., Rojas, N., and Fedele, A.: Water masses in the Humboldt Current System: Properties, distribution, and the nitrate deficit as a chemical water mass tracer for Equatorial Subsurface Water off Chile, Deep-Sea Res. Pt. II, 56, 1004-1020, https://doi.org/10.1016/j.dsr2.2008.12.013, 2009.

Silva, N. and Vargas, C.: Hypoxia in Chilean Patagonia fjords, Prog. Oceanogr., 129, 62-74, 2014.

Sievers, A. H. and Silva, N.: Water masses and circulation in austral Chilean channels and fjords, in: Progress in the oceanographic knowledge of Chilean inner waters, from Puerto Montt to Cape Horn, edited by: Silva, N. and Palma, S., Comité Oceanográfico Nacional - Pontificia Universidad Católica de Valparaíso, Valparaíso, Chile, 53-58, available at: http://www.cona.cl/ (last access: 2 October 2018), 2008.

Simmonds, E. J. and MacLennan, D. N.: Fisheries Acoustics: Theory and Practice, 2nd edn., Blackwell Science, London, 456, 2005.

Schneider, W., Pérez-Santos, I., Ross, L., Bravo, L., Seguel, R., and Hernández, F.: On the hydrography of Puyuhuapi Channel, Chilean Patagonia, Prog. Oceanogr., 128, 8-18, 2014.

Strickland, J. D. H. and Parsons, T. R.: A Practical Handbook of Seawater Analysis, B. Fish. Res. Board Can., 167, 293 pp., 1968.

Valle-Levinson, A., Castro, L., Cáceres, M., and Pizarro, O.: Twilight vertical migrations of zooplankton in a Chilean fjord, Prog. Oceanogr., 129, 114-124, 2014.

Visser, A. and Stips, A.: Turbulence and zooplankton production: insights from PROVESS, J. Sea Res., 47, 317-329, 2002.

Visser, A., Mariani, P., and Pigolotti, S.: Swimming in turbulence: zooplankton fitness in terms of foraging efficiency and predation risk, J. Plankton Res., 31, 121-133, 2009.

Whitney, M., Jia, Y., McManus, P. M., and Kunz, C. J.: Sill effects on physical dynamics in eastern Long Island Sound, Ocean Dynam., 64, 443-458, https://doi.org/10.1007/s10236-013-0681-6, 2014.

Zhou, M. and Dorland, R.: Aggregation and verticalmigration behavior of Euphausia superba, Deep-Sea Res. Pt. II, 51, 21192137, 2004. 